\title{
BUKU AJAR MATA KULIAH \\ PEMBELAJARAN BAHASA INGGRIS SD
}

Oleh

Ermawati Zulikhatin Nuroh, M.Pd.

Vevy Liansari, M.Pd.

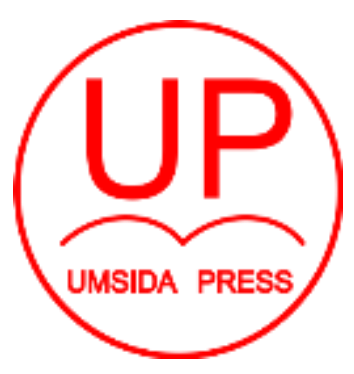

Diterbitkan oleh

UMSIDA PRESS 


\section{BUKU AJAR}

\section{PEMBELAJARAN BAHASA INGGRIS SD}

\section{Penulis :}

Ermawati Zulikhatin Nuroh, M.Pd.

Vevy Liansari, M.Pd.

ISBN :

978-623-7578-10-9

\section{Editor :}

Ummu Hani Assyita, S.Pd

\section{Copy Editor :}

Design Sampul dan Tata Letak :

\section{Penerbit :}

UMSIDA Press

\section{Redaksi :}

Universitas Muhammadiyah Sidoarjo

Jl. Mojopahit No 666B

Sidoarjo, Jawa TImur

\section{Cetakan pertama}

(C) Hak cipta dilindungi undang-undang

Dilarang memperbanyak karya tulis ini dengan suatu apapun tanpa ijin tertulis dari penerbit. 
By the end of the course students are able to:

1. to identify the differences between learning pocess in adult learners and young learners.

2. to arrange lesson plan in teaching English for primary students.

3. to explain about approach and theories of Learning by Doing or Activities based Learning in TEYL

4. to develop materials and activities in teaching English for primary students.

5. to identify kinds of media for children

Course description:

This course will cover the following materials: (1) The young language learner and its characteristics, (2) Lesson Plan for English Primary Students, (3) Learning by doing or activity-based teaching, (4) Classroom management in English for Children, (5) Opening the lesson, sequencing teaching steps, closing the lesson, (6) Assessment in TEYL. This course is important especially in preparing the students for the practice teaching English to young learners. 


\section{BIBLIOGRAPHY}

Bergeron, B.S. and M.Bradburry-Wolf. 2002. Teaching Reading Strategies in the Primary Grade. New York, NY: Scholastic Books

Bryne, Donn. 1988. Teaching Writing Skill. London: Longman Group Limited.

Brindley, G. 2003. Classroom-Based Assessment. In D. Nunan (ed); Practical English Language Teaching. New York, NY: Mc.Graww Hill, 309-338.

Brown, H. Douglas. 2007. Principles of Language Learning and Teaching (5 $5^{\text {th }}$ ed.). New York: Pearson Education.

Brown, H. Douglas. 2007. Teaching by Principles: An Interactive Approach to Language Pedagogy ( $3^{\text {rd }}$ ed.). New York: Pearson Education.

Bulletin, 1952. University of Minnesota.

Cahyani, H. 2010. A Profile of Successful English Language Learners. A Case Study of Students at Accounting Department, State Polytechnic of Malang. Paper presented in the 2nd National English Language Teachers and Lectures Conference, State University of Malang, Indonesia. March 20, 2010.

Carter, Ronald. 1988. Vocabulary and Language Teaching. New York: Cambridge.

Carter, Ronald and Nunan, David. 2001. The Cambridge Guide to Teaching English to Speakers of Other Language. Cambridge: Cambridge University Press.

Cameron, L. 2001. Teaching Language to Young Learners. Cambridge, Uk: Cambridge University Press.

Flavell, H Roger, (1985), Developing English with Young Learners. London: MacMillan Publishers Limited.

Graham, Stanley. 2013. Language learning with Technology: Ideas for Intergrating Technology in the Language Classroom. Cambridge University Press.

Georgiou-loannou, S. and P.Pavlon. 2003. Assessing Young Learners. Oxford, UK: Oxford University Press.

Grugeon, Elizabeth.,and friends. 2012. Teaching Speaking and Listening in The Primary School. New York: Dafid Fulton Publisher. 
Gunning, T. 2003, 2000. Creating Literacy Instruction for All Children. Boston, MA: Allyn and Bacon

Heilman, A. W. 2002. Phonic in Proper Perspective. $9^{\text {th }}$ ed. Upper Saddle River, NJ: MerrillPrentice Hall.

Hughes, A. 1989. Testing for Language Teachers. Cambridge, UK: Cambridge University Press.

Hutchinson, Tom and Waters, Alan. 1987. English for Specific Purposes. Cambridge: Cambridge University Press

Linse, Caroline, and David Nunan. 2005. Practical English Language Teaching Young Learners. Mc graw Hill.

Nurgiyantoro, Burhan. 2016. Sastra Anak: Pengantar pemahaman dunia anak. Gadjah Mada University Press.

Nurhadi, Ahmad. 2012. Teaching English to Young Leaners. Jombang: Universitas Pesantren Tinggi Darul Ulum.

Tarigan, H.G. 1979. Membaca Sebagai Suatu Keterampilan Berbahasa.Bandung:Angkasa

Patel, Dr. and Jain, M. Praveen. 2008. English Language Teaching: Methods, Tools, and Techniques.

Piper, T. 1993. Language for All Our Children. New York, NY: Merrill (Imprint of Mcmillan).

Wallace, Trudy.,and friends. 2005. Teaching Speaking, Listening, and Writing. International Academy of Education.

Wittich, W. A., \&Schuller, C. F. (1962). Audio Visual Materials. New York: Harper and Row Publisher.

Wayne Austin Shrope. 1972. Speaking and Listening: A Contemporary Approach. Harcourt, Brace \& World

internet source:

Arli Aditya Parikesit. (2009), Peran Bahasa Asing dalam Dunia Globalisasi [online]. Tersedia:

http://web.library.emory.edu/subjects/humanities/history/Nationalism/ [23 September 2011]

. (2010) Belajar Bahasa Inggris [online]. 
Tersedia:

http://www.belajar-bahasa-inggris.com/ [23 September 2011]

https://washburn.mpls.k12.mn.us/uploads/level 1 analytic speaking.pdf

https://dese.mo.gov/sites/default/files/ela-6-my portfolio anecdotal-

summative assessment 2-oral reading fluency rubric.pdf

https://www.thoughtco.com/writing-rubric-2081370

http://www.opem.edu/openlearncreate/mod/resource/view.php?id=56562

http://www.proenglishteacher.com/2015/04/strategi-running-dictation-untuk.html

http://nayyanrises.wordpress.com/materiku-2/paper/pembelajaran-listening-dalambahasa-inggris/

https://siftinahdliyatinniswah.wordpress.com/2016/04/11/contoh-penelitian/

http://ihanuarpratama.blogspot.co.id/2014/11/5-media-pembelajaran-untukmenigkatkan.html

https://krisnapry.wordpress.com/2012/05/09/teknik-mengajarkan-listening-pada-anak/

http://www.sekolahoke.com/2010/12/kemampuan-mendengarkan-dalam-

pelajaran.html

How_to_Teach_English_2nd_Edition_Jeremy_Harmerhttp://www.teachingenglish.org.u k/think/read/extensive.shtml

http://www.ardhyna.blogspot.com/pengertian-membaca-menurut-para-ahli?

Jaipur: Sunrise Publishers and Distributors.

https://www.sekolahbahasainggris.co.id/7-media-pembelajaran-bahasa-inggris-

terbukti-ampuh/

Mushlihin al-Hafizh. (2013). Strategi Pembelajaran Crossword

Puzzle: http://www.referensimakalah.com/2013/01/strategi-pembelajaran-

crosswordpuzzle.html

http://bemyhariadi.blogspot.co.id/2016/04/makalah-cara-mengajar-mambaca-dan.html

htps://www.aneigbal.com/2016/01/pengertian-proses-proses-jenis-jenis-aspek-aspekdan-tahap-tahap-kegiatan-membaca.html 


\section{BIODATA PENULIS}

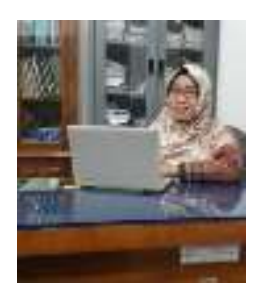

Ermawati Zulikhatin Nuroh, S.S., M.Pd. was born in Sidoarjo, July 9, 1978. She is a lecturer at Universitas Muhammadiyah Sidoarjo. Her expertise is in English Literature and Teaching English for Young Learners. She has a bachelor degree in English language and Literature Stiba Surabaya in 2001, and she has graduated her S2 of Language and Literature Education in English Education Study Program of State University Surabaya in 2009. Her first teaching career began at Primary School Teachers Education study program at Universitas Muhammadiyah Sidoarjo in 2010. Instead of teaching, she has conducted some research about teaching and literacy, then published as articles in journals and Seminars. Erma has published two books about English teaching. She is enthusiast to develop the research in teaching related to Teaching English for Young Learners.

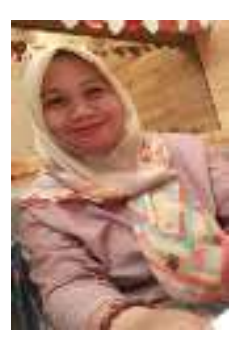

Vevy Liansari, S.Pd., M.Pd. was born in Surabaya, September 18, 1987. She is a lecturer at Muhammadiyah University of Sidoarjo in 2014. In 2010, she graduated her S1 in English Education Study Program of State University Surabaya. Moreover, she continued her S2 in English Education Study Program of State University Surabaya. She graduated her study in 2012. She is actively in teaching learning process, writes articles in journals, joins activities at campus such as workshop, calls of paper, and training activities. 
Teaching English for Primary Teachers is written to fulfil students' needs to teach English for elementary school and as a handbook Pembelajaran Bahasa Inggris SD for elementary school teachers' students (PG-SD). This book is designed to provide an opportunity to develop students' English teaching skills more creatively, meaningfully and communicatively.

It consist of seven units, they are; introduction to teaching English for primary school. language themes for elementary school, classroom language for primary school, principle of teaching language for primary school, teaching English with media, and assessing English in young language learners. The material have been arranged and graded in accordance with their language levels.

Above all, to improve the quality of this book, criticsm and suggestion for better edition are highly appreciated. 


\section{COVER}

PREFACE

TABLE OF CONTENT

\section{CHAPTER I TEACHING LISTENING}

1.1 Definition of Teaching Listening .................................................... 1

1.2 The Development Listening Skills ......................................... 4

1.3 Teaching and Listening Technique..................................................... 7

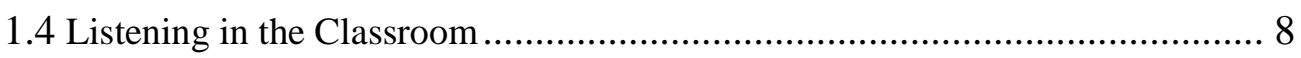

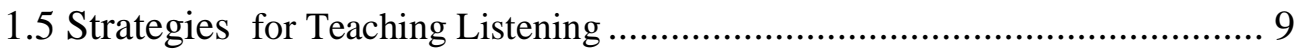

1.6 Methods in Teaching Listening...................................... 10

1.7 Media in Teaching Listening ............................................... 13

\section{CHAPTER II TEACHING SPEAKING}

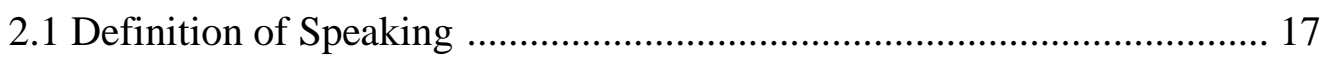

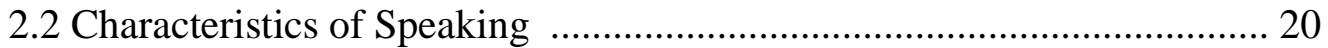

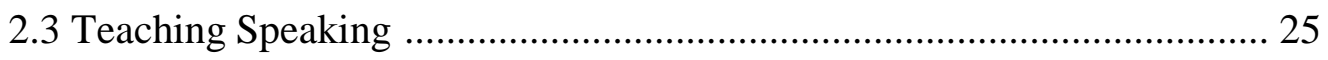

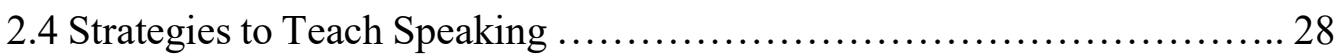

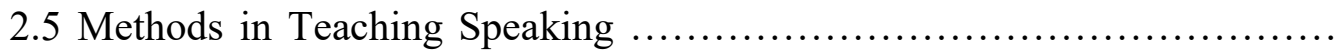

29

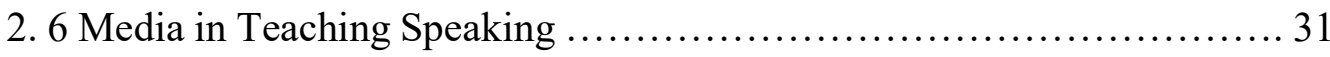

\section{CHAPTER III TEACHING READING}

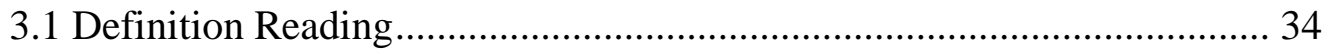

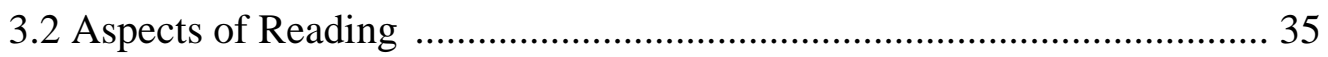

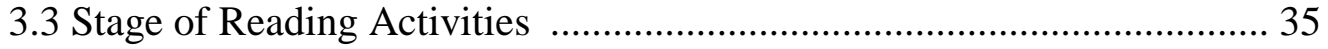

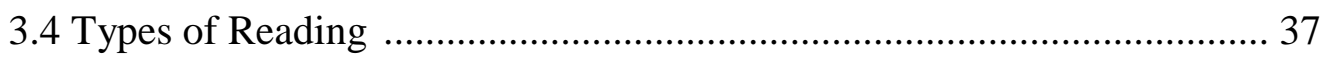

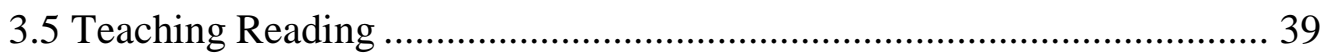




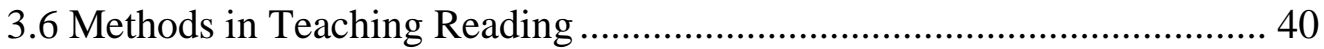

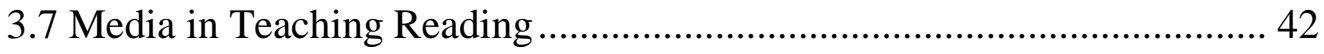

\section{CHAPTER IV TEACHING WRITING}

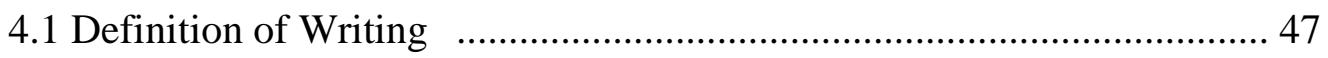

4.2 The Characteristics of Writing ........................................................... 50

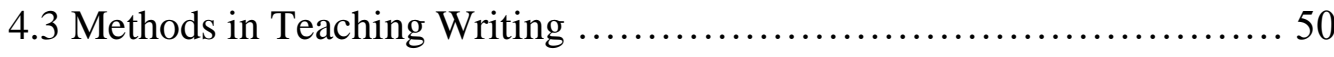

44. Types of Writing ................................................. 55

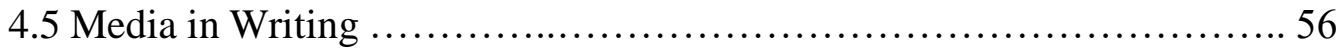

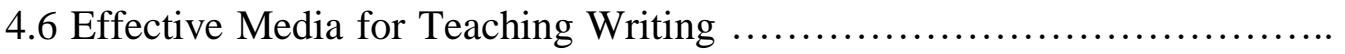
60

4.7 Difficulties in Writing English ..................................... 66

4.8 The Principles of Good Writing Materials .................................

67

\section{CHAPTER V ASSESSING ENGLISH IN YOUNG LEARNERS}

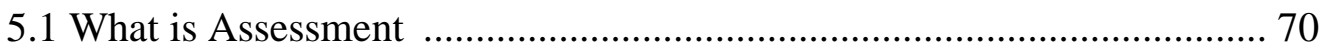

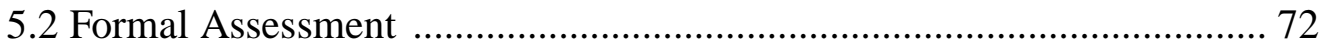

5.3 Classroom-based Assessment ............................................................... 74

\section{BIBLIOGRAPHY}

AUTOBIOGRAPHY 


\section{CHAPTER I TEACHING LISTENING}

\subsection{Definition of Teaching Listening}

Listening is our understanding of listening to English. Either directly or through media such as music or movies. Listening is an important material in English because we should be able to know what people are saying to us. To be able to master listening we must really understand the words we hear.

According to the Bulletin (1952) said that listening is one of the basic language skills. It is a medium where children, young people and adults get the most of their education, their information, their understanding of the world and human affairs, their ideals, the sense of values, and their appreciation. In today's mass communication, it is very important that our students are taught to listen effectively and critically.

Listening to and understanding the talks involves a number of basic processes, some depending on linguistic competence, some depending on previous knowledge that is not necessary purely linguistic, and some depending on the variables That affects the mobilization of competence and knowledge in a particular task situation. Listeners must have a continuous set to listen to and understand, and as he hears the speech, he can be assisted by several types of sets to process and recall the transmitted information. His linguistic competence allows him, perhaps, to recognize the formatives of the heard speech, for example; to dissect the waveform of the morpheme, words, and other meaning-bearing elements of the speech. 
Listening is a receptive skill, and receptive skills give way to productive skills. If our students produce something, teaching will be more communicative. This brings us to the necessity of integrating language skills. There are two reasons to use integrated activities in a language class:

1. To practice and extend the use of learners ' of specific language structures or functions

2. To develop the ability of learners in the use of two or more skills in real context and communicative frameworks.

The integrated activities, on the other hand, provide a variety in the classroom and thus maintain motivation and allow recycling and revision of languages that have been taught separately in each skill. How can we be confident that the listening experience will be more productive. Wittich tells us to distinguish the four levels that exist in listening to radio or recording:

- Level 1

This mood is listening. Here, the sound is still backed up there is usually limited understanding, and indeed, attention is limited. One becomes instantly aware of the sound only when they stop. However, some learning can occur.

- Level 2

Here the goal is relaxation, escape, get your mind off something rather than on it. The material is understood, but usually not analyzed for value. Listening to this can lead to useful ideas, but they are usually peripheral and are unintentional.

- Level 3

At this level, the answer is sought as a key to the action. One listening to weather reports, traffic information from the airplane-while useful, but what we call information while forgotten. The listening form does not require a long time, sustained concentration. 
- Level 4

This is an analytical and critical stage of listening. Listeners are not only looking for serious answers to serious questions, but evaluate the quality of answers. A round table discussion, listening to serious talks, passionate conversations, symphonic music is on the fourth level. At this stage, listening to music requires attention and is not motivated as it was at the previous level (Wittich and Schuller, 1962).

It is listening at the fourth level which is mainly our concern in teaching us. Listening can add emotional and dramatic qualities. Radio and recordings highlight the importance of listening. Listening is active as it speaks (other receptive skills), and in some ways is even harder. It also requires attention, thought, interpretation, and imagination. To improve students ' listening skills, namely (Austin Shrope, 1970):

1. Adopt a positive attitude

2. Be responsive

3. Close the interference

4. Listen for the speaker purpose

5. Look for signals from what's to come

6. Look for a summary of what has happened before

7. Evaluation of supporting materials

8. Looking for non-verbal instructions.

In listening activities, we listen for a purpose. We make a direct response to what we hear. There are some visual or environmental clues to the meaning of what is heard. The stretch of hearing discourse comes in short chunks, and the discourse is most heard spontaneously, because it differs from the formal oral prose in the amount of ' noise ' redundancy and the colloquial language, and the character of his hearing. 
In listening to English as a foreign language, the most important feature can be defined as:

1. Cope with the sound

2. Understanding intonation and stress

3. Overcoming Redundancy and noise

4. Predict

5. Understand Everyday Vocabulary

6. Fatigue

7. Understand different accents

8. Using visual and environmental instructions.

\subsection{The Development Listening Skills}

Teachers of young learners know the importance of teaching children how to listen. This is true for both a second-and foreignlanguage learners, it is useful to consider the listening skills that are taught to children learning English as a first language. For example, a five year old native speakers who is not able to listen to and follow simple instructions is probably not going to be ready to learn academic content such as colours, numbers, shapes, days of the week, letters, and sounds. The same holds true for non-native student. Being able to follow simple instructions is one of the foundation listening readiness skills that get children ready to develop other language skills (Linse \& Nunan; 2005: 27).

Listening skill also help children who have literacy skills in their own language transition into English language literacy. Look at figure 1 to see how the development of different listening skills helps children get ready to read. Listening skills prepare children for reading in their native language as well as reading in foreign language. 


\begin{tabular}{|c|c|}
\hline Skill & How it Prepares for Reading \\
\hline $\begin{array}{l}\text { 1. Listens to and follows } \\
\text { instructions such as } \\
\text { "take out your pencil } \\
\text { and your green activity } \\
\text { book" }\end{array}$ & $\begin{array}{l}\text { Prepares children for a variety } \\
\text { of academic tsks }\end{array}$ \\
\hline $\begin{array}{l}\text { 2. Can follow an oral } \\
\text { sequence of events such } \\
\text { as "Lucy went to the } \\
\text { refrigerator and took } \\
\text { out some milk" }\end{array}$ & $\begin{array}{ll}\text { Prepares children to } \\
\text { comprehend stories }\end{array}$ \\
\hline $\begin{array}{l}\text { 3. Can listen attentively to } \\
\text { stories }\end{array}$ & $\begin{array}{l}\text { Prepares children } \\
\text { comprehend stories }\end{array}$ \\
\hline $\begin{array}{l}\text { 4. Can comprehend a story } \\
\text { that has been read } \\
\text { and/or told }\end{array}$ & $\begin{array}{l}\text { Prepares children to } \\
\text { comprehend stories }\end{array}$ \\
\hline $\begin{array}{l}\text { 5. Can discriminate } \\
\text { between sound such as } \\
\text { /b/ and /p/ }\end{array}$ & $\begin{array}{l}\text { Prepares children to decode } \\
\text { words/helps to prepare } \\
\text { children for phonics instruction }\end{array}$ \\
\hline $\begin{array}{l}\text { 6. Can identify rhyming } \\
\text { sounds }\end{array}$ & $\begin{array}{l}\text { Prepares children to decode } \\
\text { words/helps to prepare } \\
\text { children for phonics instruction }\end{array}$ \\
\hline $\begin{array}{l}\text { 7. Can segment (or } \\
\text { separate) words into } \\
\text { syllables such as ap-ple } \\
\text { or din-ner }\end{array}$ & $\begin{array}{l}\text { Prepares children to decode } \\
\text { words/helps to prepare } \\
\text { children for phonics instruction }\end{array}$ \\
\hline
\end{tabular}

Figure 1 Listening skills for young learners (Linse \& Nunan; 2005: 28) 
- Listening skills to prepare children to read

When a teacher shares a story with children and helps them to develop listening comprehension skills, she is also working on their reading readiness skills. Listening comprehension utilizes many of the same process necessary to read and comprehend a story (Piper, 1993). Listening capacity refers to an informal measures of one's ability to understand or comprehend spoken language in the context of a story being told or read aloud (Gunning 2003, 2000). As a foundation for reading, we need to develop children's listening comprehension and listening capacity.

Children who can segment words and listen to isolated sounds have developed phonological awareness. Phonological awareness refers to the ability to listen and think about the entire range of sounds that occur in a word (Heilman, 2002), for example, words are made up of phonemes-individual sounds-as well as syllables. By developing listening skills that focus on phonological awareness, children will be better prepared to participate in phonics instruction which, in turn, will make it easier for them to decode and read words.

If children have been trained a carefully listen to English language sounds, they will be in a much better position to match the sound with a specific letter or symbol. Consequntly, if children haven't developed phonological awareness, they can be very confused when they begin reading instruction. For instance, if children have trouble discriminating $/ r /$ and $/ I$, they could have trouble with a phonic lesson focused on these sounds. It is much easier to learn how to listen to sounds first and then only later add the print. 
- Auditory patterns

Another way to think about the relationship between listening and reading is to consider the fact that one needs to recognize pattern in order to read. Reading is about patterns. Detecting the auditory or phonological patterns that occur in language will better prepare children for the visual patterns that occur in English language words. In English, unlike some other languages, there are many single syllable words that rhyme. Rhymes are an important components of many English language songs, finger plays, and chants for children. By learning to recognize rhyming words, children will be in a better position to decode and read words that follow a similar pattern.

\subsection{Teaching and Listening Techniques}

The ability to listen in English lessons is one of the competencies that students must master. Teachers as facilitators need some techniques in order to listen in the classroom is not monotonous and boring. There are some techniques for listening skills that can be applied in the classroom.

\section{Filling Gap}

This technique can be done by blanking a few words in paragraphs or dialogs. Have students listen to the oral text through the teacher or recording and fill in the blank words.

\section{Guessing Picture}

This technique can be done by guessing the image according to spoken text that is read or listened to

\section{Finding Mistakes}

This technique is done by requesting listening to the oral text and highlighting words that do not correspond to the oral text 


\section{Choosing Menu}

This technique is done by asking students to select a menu that corresponds to the oral text.

5. Rearranging Sentence or Paragraph

This technique is done by giving a sentence or paragraph of the House to the student. Students are asked to listen to the oral text and make the paragraph correct.

\section{Matching}

This technique is done by splitting the conversation into two parts. The first section contains half sentences and a second half sentence. Then students are asked to listen to the text of the conversation and then match the first and second sections according to the conversation text.

7. Listen and Imitate

The teacher will show a picture then will be pronounced with a clear pronunciation, then the pupil will impersonate what the teacher said.

8. Whispering Game

The teacher will whisper one English word to the appointed student, then the student continues to whisper the same word to his friends until the latter person pronounce it aloud and correctly.

9. Listen and Follow

The teacher will give a commandment to the students and students will do the commandment given by the teacher, example: "Show Your Teeth" then the pupil will do so.

10. Listen and Match

Students are given pictures. For example, pictures some fruits. Teacher pronounces then students give an image number. This activity can be done by sharing an image with each student. Then the teacher mentions the fruit name. The student holding the picture of 
the fruit stands while showing the picture. If wrong give a mild sentence, for example asked applause 10 times while saying sorry.

\subsection{Listening in the Classroom}

Most children's course books include listening activities where children listen and do something. For example, the children listen as the teacher reads the script or plays the radio recording and write the numeral for the corresponding picture.

There are also course books that incorporate listen with reading. Students, for example, may listen to a passage and then answer questions that they hear on an audio recording or read aloud. A course book designed for nine years olds who have English language literacy skills and have studied English for several years. It is important to make sure that the students have the literacy skills to do the exercise. For example, students would have to be able to read the irregular spelling pattern ph for the sound / $f$ / in order to recognize the word dolphin. You could very easily adapt into an activity that only involved listening by having students hold up the yes/no cards while you read the questions aloud (Linse \& Nunan; 2005: 41).

\subsection{Strategies for Teaching Listening}

\section{Ask questions to help students listen}

According to Flavell, H Roger, (1985) "when students perform listening activities in English, they should not be expected to understand every word of what they hear". They may just understand a few words. It can be frustrating for students if they don't understand what they're listening to, so keep them patient. The listening activities you do in the classroom should help them develop their listening skills over time. One way to do this is to give your students a question to 
think about before they listen. Just as it is important to ask students questions before they read the text (see support units read to understand), ask questions before students listen to something can also help them.

- Orient them to what they will listen to.

- Help them learn to choose keywords or important, and use these words to try to understand what is being said.

- Helping brands are more interested in what they listen to when they try to find out the answers to questions while listening, they listen actively.

\section{Using audio recordings}

There are some listening activities that you can do with students in your class. However, it can also be good for students to listen to other voices. You can do this by bringing audio recordings to the classrooms. Some examples are:

- Recordings, recorded from the radio and played on a tape recorder

- Songs played on tape recorders or CD players

- Songs played on an MP3/4 player or mobile phone

- Audio recordings made by teachers, students or others with mobile phones (for example, teachers can record dialogue)

- Audio books played on a CD player or downloaded to a laptop or MP3 player

- Audio recordings downloaded to your phone or laptop (see source 3) or a link to an audio recording that has been developed for English learners.

\subsection{Methods in Teaching Listening}




\section{Interpersonal Activities}

One of the most effective and unthreatening ways for students to develop more powerful listening skills is through interpersonal activities, such as mock interviews and storytelling. The work of students in a small group of two or three, and then gives them a listening activity of a certain thing to accomplish. For example, you could ask one student to interview another for a job with the company or for an article in the newspaper. Even storytelling activities, such as answering the question "What's your favorite movie from last year?"Can give students the opportunity to ask each other and then practice active listening skills.

\section{Group activities}

Larger group activities also serve as useful methods for teaching listening skills to students. You can start with a simple group activity. For the first part, divide students into groups of five or more and instruct them to study one hobby or interest at least of two other group members. Ask them to ask clarification questions during the activity, and you can allow them to make a note if it helps. However, as their time and skills grow, you have to restrict students from just writing notes after the completion of the first part of the group's activities. For the second part, ask students to sit in a large circle, and then ask each student to share the name and hobby or interest of the member of the group he met. The second part of this group activity can also provide additional exercises to listen to. For example, you might ask students to name a number of hobbies and interests identified during a sharing session.

\section{Audio Segments}


You can also teach listening skills through audio segments of radio programs, online podcasts, instructional lectures, and other audio messages. You should make this interactive listening process model in class with your students, and then instruct them to repeat the exercise itself. First, instruct students to prepare to listen by considering whatever they want to learn from the contents of the audio segment. After they have written or shared these ideas, then play the audio segment, which allows students to make notes if they are helpful. Once they gain confidence and experience, repeat this activity, but instruct students not to make notes until the completion of the audio segment. You can use shorter or longer audio segments, and you can choose more accessible or more challenging material for this type of exercise.

\section{Video Segments}

Another useful resource for teaching listening skills is the video segments, including short sketches, news programs, documentary films, interview segments, and dramatic and comedy materials. As with any audio segment, select the section and length of the video segment based on your students ' skill levels. With your students, first watch the segment without sound and discuss it together. Encourage students to identify what they think will be the content of the segment. Then, watch that segment again, this time with the sound, which allows students to take notes if it is beneficial to their skill level. Once the video segments are completed, you can ask students to write a short summary of the segment, or you can take the time to discuss as a group how the segment compared to the students ' expectations.

5. Instructional Tips 
Whatever method you use to teach listening, keep in mind some key instructional tips that will help you and your students navigate the learning process.

- Keep your expectations simple, because the most experienced listeners will not be able to fully and accurately remember the whole message.

- Keep your directions accessible and build opportunities for students not only to ask clarifying questions, but also to make mistakes.

- Help students navigate the anxieties of their communication by developing activities that are appropriate to their level of skill and confidence, and then strengthening their confidence by celebrating the ways in which improvement they Do, no matter how small.

\subsection{Media in Teaching Listening}

The Media in general learning is the tool of teaching learning. Everything that can be used to stimulate the mind, feelings, attention and ability or skills of learning so that it can encourage the occurrence of the learning process. This limitation is quite broad and profound, including the understanding of sources, the environment, human and technical that used for learning or training purposes, (Haryanto, 2012).

In selecting learning media, it needs to be adapted to the needs of each student's situation and condition. In fact, it is not a learning medium that determines learning outcomes. It turned out that success uses learning media in the learning process to improve learning outcomes depending on (1) message content, (2) How to explain the message, and (3) The characteristics of the message 
recipient. The learning process is a process of communication and takes place in a system, so the media learning occupies a position that is quite important as one component of the learning system. Here are the media used in learning listening:

\section{Film}

The films used as a learning media are of course in English. In addition to English, it is not possible to use a movie that has subtitles or commonly referred to as subtitles. The Film is one of the visual media that almost everyone has liked. The Media is suitable for learning listening to children.

By using a movie that is linked, the child can learn listening with fun without getting bored. It would be more effective to see the film as the child is directed to write the piece of dialogue spoken by the actor or its actors and match it with the transcript of the original dialogue. With this method the child can find out the mistakes and shortcomings in the child's self. This self-evaluation will then be able to measure the child's listening skills.

\section{Song}

Today's Western songs/English language has become a new trend in the world of Permusikan. Educators can take advantage of this opportunity to improve their child's listening skills. The song is the only media that is easy to obtain and used as a learning resource. The number of western songs available will make learning more varied.

To maximize listening skills, learners can listen to western songs as often as possible with the guessing of the lyrics that are in them and matched to their original lyrics. In addition to improving listening skills, this method can also improve the ability vocabulary children. Listening to a song that uses English as the lyrics will make learning to learn English fun. By using the song as a medium, we can learn the four aspects of listening learning at once. This is one of the 
approaches to improving our ability to learn English, as well as to motivate students to improve their English listening skills. According is listen only. It is to familiarize the ears with English pronunciation.

- Listen

Hearing is not the same as listening. Listening is an activity only need to carry a small note. Listen carefully to the song, then record spoken lyrics.

- Match

The final activity to improve the listening skills with the song is to match with the original lyrics. Then interpret the lyrics as a whole. One thing to note is the meaning of a word depends on the context of the sentence.

3. Video

Besides using movies, improving listening skills can also be done through learning videos. The videos used are video learning about listening skills of course, both speeches, conversation, dialogue and others. Although this method looks a bit formal and not so fun on appeal with music and movies, but the method proves to be effective enough to learn to improve listening skills. Teachers can look up listening videos on the Internet or on YouTube.

\section{Game}

Actually, listening methods using this one media are quite difficult because of the limited types of games for PC and gadgets that can improve listening skills. Although it is not much of a medium, but the advantages of this method are very enjoyable in the appeal with other media. To learn listening using the game, it seems that the teacher should be good at looking for the learning media.

\section{Audio Visual}

Using audio visual media can improve students ' listening skills. In the process of learning to teach teachers should be implemented by 
means of audio visual, because it can help students understand the material. And also students can facilitate themselves to learn everywhere, because audio visuals such as videos or movies are interesting and easiest to find and use.

\section{Audio}

Using audio media can improve learning to listen to students. The use of audio media in listening will be maximized if the teacher optimizes the learning time available. It is hoped that teachers will modify the teaching way more often, so that they can improve their listening learning. 


\section{CHAPTER II}

\subsection{Definiton of Speaking}

Speaking activity can be interpreted as Speaking activities, Where the speaking activities in question are speaking in English. If viewed from the origin of The word "Speaking" comes from the word speak which is "speak is to express opinions; To say; to converse ". So speak here is how to remove or express an opinion, the words we want to speak. That's the sense of simple speaking and word from speaking. But in the broad sense of speaking has a considerable shell in our lives. A day many people in this world who have issued his opinion so that we can follow, conclude and also take the attitude of what they expressed.

The main system when individuals speak and produce sound, i.e. vocals, larynk, subglottal systems, which consist of lung and multiple muscles combined for breathing and release of air and Throat. Through speaking or speaking activities we can interact with the world wide community. In speaking we seem to be doing the translation in doing so that indirectly makes our brains work twice.

This can be described as when the child is given a question and then you prepare it first in its preparation stage in a good and true Indonesian language. Then move it or synchronize it into English which is certainly in the correct pattern, thus our brains will work twice. But it is different when we immediately think of sentences in English. child will have difficulty in this, because in halspeaking or talking the child must be skilled in using the vocabulary and the Ordinance to use it. Speaking difficulties are usually caused:

1. It is difficult to express ideas orally (speaking).

2. Limited vocabulary (vocabulary). 
3. Limited grammar skills. So it is difficult to speak with the correct rules.

4. The limited pronunciation of words (pronounciation). Making it difficult to pronounce words It is properly said.

5. The lack of courage to speak for fear of the Selian, there are factors that can be used in aspects of discussion, namely:

- The accuracy of speech (pronunciation).

- The emphasis

- or placement of the appropriate tone and duration.

- Election

- Accuracy of speech targets.

But if you see from the element of habit, after the observe it turns out that many people who can or fluently in English speaking because it is accustomed. And further reinforce the notion of experts that "practice make it perfect" or can get used to. For students who are highly motivated, usually they want fast results and even after the first lesson, students have wanted to show their friends or family members that they can speak English. Thus, they need to be given the opportunity to speak English as quickly and as possible.

In addition, speaking refers to communicating our thoughts orally (Djiwandono, 2008: 118). By expressing one's thought, one can make the listeners understand what is going on his thought. To make them understand what he thinks, one has to speak clearly. This means that:

1. One has to make the sounds of speech loud and clear enough so that the listeners will understand.

2. One has to choose the words which convey his message without any distortion. 
There are some other experts who defined speaking. Hornby (2005: 1467), for instance, defined that speaking is making use of our own voice to say something, and to be able to use a particular language. Furthermore, Boesch stated that speaking is communicating information through the spoken word. In speaking activity, the presence of the speaker and the listener is important to build mutual conversation. Thus, speaking is considered as unity to communication.

In addition, Richards and Renandya (2002: 204) explain that effective oral communication requires the ability to use the language appropriately in social interactions that involves not only verbal communication but also paralinguistic elements of speech such as pitch, stress, and intonation. Moreover, nonlinguistic elements such as gestures, body language, and expressions are needed in conveying messages directly without any accompanying speech. Brown (2007: 237 ) says that social contact in interactive language functions is a key importance and in which it is not what you say that counts but how you say it what you convey with body language, gestures, eye contact, physical distance and other nonverbal messages.

Communication is an important part of human civilization and it is a means of cultural transformation. In addition, it means that communication is the ways in which we get in touch with each otherhow we show each other our feelings; tell each other our thoughts; ask question; ask for help; pass on fact; argue; persuade others to do what we want them to do; explain; and give orders.

Putting all these points together, now we can make a simple definition of speaking as the process of conveying the message orally from the speaker to the listener so that the response given is correct. 


\subsection{The Characteristics of Speaking}

There are four language skills in English language learning: listening, speaking, reading, and writing. Those skills, then, can be classified into receptive skills (listening, reading) and productive skills (speaking, and writing). Since, speaking belongs to productive skill; it requires a lot of back-up factors like knowledge, confidence, self esteem and enthusiasm; and particularly, it brings about its own prerequisites: exposure, consolidation, motivation as well as acknowledgment (Ali, 2010: 1). Whether we realize it or not, these determinant factors can be made to exist in a supportive learning environment of English as a Second Language (ESL).

Moreover, researchers often describe it as a complex and multilevel skill. Part of the complexity is explained by the fact that speakers need to use their knowledge of the language and activate their ability to do this under real constraints. (Djigunovic, 2006: 12).

Even though writing also belongs to productive skill, speaking is claimed as difficult as writing due to some reasons as follows: (1) speaking is a direct communication, (2) speaking related to some other language components (stress of words, pronunciation, etc) and (3) speaking is spontaneous one. Besides, characteristics of those two productive skills are quite different as compiled by O'Malley and Pierce (1996: 58). In their book it is stated that in speaking, native speakers do not typically use complete sentences, use less specific vocabulary, use syntax in a loosely organized manner, and make frequent use of discourse markers (e.g. well uh-huh, etc.). Based on the characteristics, speaking serves as the natural means of communication between members of community both for the expression of thought and as a form social. Speaking is an important skill in English language learning (ELL) since it is the skill that is used in everyday life as part of everyday interaction. Thus, mastery 
of speaking skill becomes the priority for many language learners. Nevertheless, as we can see nowadays, some learners may have known the language use, but they cannot use the language. Therefore, by describing the learners' strategies in improving their speaking ability, it is expected that the learners not only know the usage of a language but also they can use the language actively in their daily interaction.

Like walking, eating, or cycling, speaking is a matter of habit. Therefore, to be able to walk, eat, cycle, and speak we have to make it habit by practicing lots and repeating it again and again. Through constant practicing and repeating, those activities become automatic, and this is the important requirement to be able to speak fluently. Simply put, automaticity is the ability to do things without occupying the mind with the low level details required, allow it to become an automatic response pattern or habit. It is usually the result of learning, repetition, and practice. Learning to ride a motorcycle, for example, is hard for the first time. We have to concentrate on what to do, when prevent the motorcycle from hitting the tress along the roads. We have to think about when to use the rear-view mirror, when to change to gear, when to use the brake and clutch lever, and so forth. Nonetheless, after a few times, we do not need to concentrate much on them as it becomes automatic.

Related to speaking, automatic processes refer to processing in a more accomplished skill, where the "hard drive" of our brain can manage hundreds and thousands of bits of information simultaneously. Automatic processing is generally characterized as fast, relatively unstoppable, independent of the amount of information being processed, effortless, and unconscious (Segalowitz as cited in Brown, 2007: 300). In contrary, controlled processes are typical of anyone learning a brand new skill in which only a very few elements of the skill can be retained. In short, controlled processes 
are capacity limited and temporary, while automatic processes are relatively permanent (Brown, 2007: 300).

In conclusion, the automaticity is the later stage in speaking in which the speakers have already learnt, practiced, and repeated lots. At the first time we learn to speak, everything seems to be controlled. Thus, the activity of speaking is restricted to repetition and drills, so the speakers have to pay more attention to the accuracy. Nevertheless, the more they practice, they will move to the automatic stage in which they do not give more attention to the accuracy, but to the fluency. It means that to be able to speak fluently, one as to move away from processing language unit by unit, piece by piece, focusing closely on each, and "graduate" to a form of high-speed, automatic processing in which language forms (words, affixes, word order, rules, etc) are only the periphery of attention (Brown 2007: 64). In other words, overanalyzing language, thinking too much about its forms, and consciously lingering on rules of language all tend to impede this graduation to automaticity.

The principles of automaticity does not say that focusing on language form and rules is harmful as adults can benefit greatly from certain focal processing of rules, definitions, and formal aspects of language. What the principle does say is that adults can take a lesson from children by speedily overcoming our tendency to pay too much focal attention to the bits and pieces of language and to move language forms quickly to the periphery by using language in authentic contexts for meaningful purposes (Brown, 2007: 65). 
To make clearer, here is the EIF framework which shows the stages in speaking:

Controlled process

process

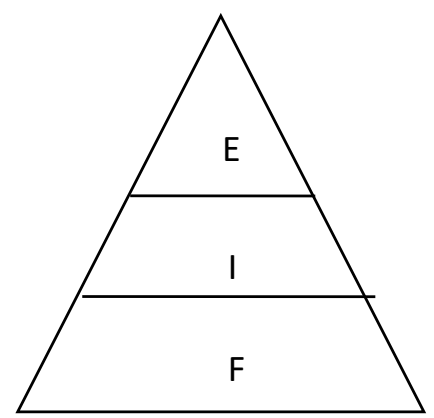

Controlled

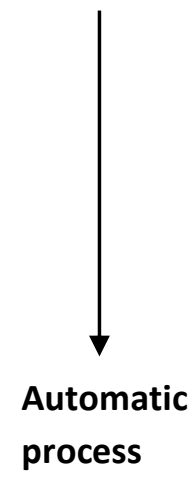

Figure 2.1: EIF Framework (Boesch, D.)

Where: $\quad E=$ Encounter

$$
\begin{aligned}
& \mathrm{I}=\text { Internalize, and } \\
& \mathrm{F}=\text { Fluency }
\end{aligned}
$$

\section{E (Encounter)}

Students encounter the target language activities like memorizing vocabulary items, watching and following the model, etc.

\section{I (Internalize)}

Students internalize the target language through practice (controlled process activities $\rightarrow$ free practice activities). The activities can be in form of dialogues, pair conversations, etc. 


\section{F (Fluency)}

Students use the target language on their own. Role-play is an instance of the activity used in this stage.

Based on the explanation above, we can see that fluency or automaticity in speaking develops gradually, that is form controlled one the automatic one, or from dependence to independence. Each part of the figure 2.1 represents the time needed to work on each stage. Thus, to achieve fluency, the learners will need more time until they become fluent in using such a language.

\section{Pronunciation}

Most people think of pronunciation as the sounds waves made while speaking. However, Carter \& Nunan defined that pronunciation deal with the production and perception of the significant sounds of a particular language in order to achieve meaning in contexts of language use (2001: 56). It shows that as speakers of a language, we need to be able to understand each other with relative ease. The degree to which students acquire perfect pronunciation seems to depend very much on their attitude to how they speak and how well they hear. How we pronounce words, phrases, and sentences communicates to others considerable information about who we are, and what we are like, as people. Thus, pronunciation help allows students to get over serious intelligibility problems.

\section{Vocabulary}

In learning language, especially English as a second language, the students need to master vocabulary. More vocabulary are mastered by students will make their performance better in all 
aspects of learning language. According to Nunan words are clearly vocabulary (2003: 130). Carter \& Nunan added that learning vocabulary are key components concerning how words are learned (2001: 42). It shows that vocabulary is an important component of language. Furthermore, Deighton (1971: 461) stated that vocabulary is the most component of language power. In using a language, students who are rich in vocabulary will be successful both in expression skill: speaking and writing, and receptive skills: listening and reading. But those who are poor in vocabulary will get troubles in those skills. Here, teachers help learners with vocabulary directly or explicitly by means of word lists and paired translation equivalents. In addition, they also help learners by more indirect or implicit means, such as exposure to words in the context of reading real texts.

\subsection{Teaching Speaking}

Teaching speaking should be taught in attractive and communicative activities. There are many types of classroom speaking activities. Harmer (2001: 348-352) states six classroom speaking activities. They are acting from script, communication games, discussion, prepared talks, questionnaires, simulation, and role play.

\section{Acting from script}

Playing scripts and acting out the dialogues are two kinds of acting scripts that should be considered by the teacher in the teaching and learning process. In the playing scripts, it is important for the students to teach it as real acting. The role of the teacher in this activity is as theatre directors, drawing attention to appropriate stress, intonation, and speed. This means that the lines they speak will have real meaning. By giving students practice in these things before they give their final performances, the teacher ensures that acting out 
is both a learning and language producing activity. In acting the dialogue, the students will be very helped if they are given time to rehearse their dialogues before the performance. The students will gain much more from the whole experience in the process.

\section{Communication games}

Games are designed to provoke communication between students. The games are made based on the principle of the information gap so that one student has to talk to a partner in order to solve a puzzle, draw a picture, put a thing in the right order, or find similarities and differences between pictures. Television and radio games, imported into the classroom, often provide good fluency activities.

\section{Discussion}

Discussion is probably the most commonly used activity in the oral skills class. Here, the students are allowed to express their real opinions. According to Harmer (2001:272) discussion range is divided into several stages from highly formal, whole-group staged events to informal small-group interactions.

The first is the buzz groups that can be used for a whole range of discussion. For example, students are expected to predict the content of a reading text, or talk about their reactions after reading the text.

The second is instant comments which can train students to respond fluently and immediately is to insert 'instant comment' mini activities into lessons. This involves showing them photographs or introducing topics at any stage of a lesson and nominating students to say the first thing that comes into their head.

The last is formal debates. Students prepare arguments in favor or against various propositions. The debate will be started when 
those who are appointed as 'panel speaker' produce well-rehearsed 'writing like' arguments whereas others, the audience, pitch in as the debate progresses with their own thoughts on the subject.

\section{Prepared talks}

Students make a presentation on a topic of their own choice. Such talks are not designed for informal spontaneous conversations because they are prepared and more 'writing like'. However, if possible students should speak from notes rather than from a script.

\section{Questionnaires}

Questionnaires are very useful because they ensure that both questioner and respondent have something to say to each other. Students can design questionnaires on any topic that is appropriate. As they do so the teacher can act as a resource, helping them in the design process. The results obtained from questionnaires can then form the basis for written work, discussions, or prepared talks.

\section{Simulation and Role play}

Simulation and role play can be used to encourage general oral fluency, or to train students for specific situations. Students can act out simulation as them or take on the role of completely different character and express thoughts and feelings as they doing in the real world. Those activities can be used by teachers to teach speaking. Teachers can choose an activity that related to the topic and objective of the lesson. Besides, they must consider the situation, condition of the students and materials that will be taught. For example, they use simulation and role play activities when they teach expressions. Teachers can ask them to write some dialogues and after that they have to act them out in front of the class. It may be used by the teachers in using acting from script. In discussion, teachers can use 
some pictures or maybe videos in a certain situation. These activities can be used as the way to measure how far students can speak, say and express their feeling in English.

\subsection{Strategies to Teach Speaking}

From a communicative purpose, speaking is closely related to listening. The interaction between these two skills is shown in the conversation. Brown (2001: 275-276) states that there are seven principles for designing speaking techniques.

1. Use techniques that cover the spectrum of learner needs, from language based focus on accuracy to message-based on interaction, meaning, and fluency.

2. Provide intrinsically motivating techniques.

3. Encourage the use of authentic language in meaningful contexts. 4. Provide appropriate feedback and correction.

5. Capitalize on the natural link between speaking and listening.

6. Give students opportunities to initiate oral communication.

7. Encourage the development of speaking strategies.

The process of teaching speaking itself can be done in several stages. Scott (1981) mentions three stages to complete the teaching of speaking. The first stage is stating objectives. The teacher has to put across what operation the students are going to learn. When the students understand the objectives of learning, the instruction will be done communicatively. The teacher could tell students the objective of the lesson directly. Giving students clues for brainstorming the objectives is preferable. Another way is using visual aids to attract students' attention and participation.

The next stage is presentation. One thing that should be considered in this stage is the whole language operations that will be 
given in the lesson are presented in context. It is very important to make language items clear. To contextualize a language item, the teacher can use text, video, recorded or picture in the form of transaction of native speaker and the like. The last is practice and production. Drilling check will be given to the students in the phase to see if they have understood of what is being learnt through oral repetition of language presented and then move to individual responses. The teacher will direct the students by providing information gap and feedback for students. And the students' replies are not only seen from the grammatical accuracy point of view but rather of language appropriateness and acceptability.

Then, there are some important points that should be considered in teaching speaking to young learners. The first thing to be considered is who the learner is and why they are. The clear objective is the next. In the end of the lesson, students at least are able to do something using oral English. The third is since the final objective of learning speaking is communication, all materials that are given to the students such as vocabulary, grammatical structures, and other language items, are expected to be applied by students in the daily life. Teacher's role in the speaking learning is creating activities in which the students can practice and apply what they have learnt orally. In other words, this is the turn of the students to practice communication.

\subsection{Methods in Teaching Speaking}

\section{Pre-Communicative Activity}

Pre-Communicative Activity presents memorization of dialogue. Memorize sentences in a dialogue and dramatize them. 
a. Dialogue through pictures, namely the teacher brings pictures and shows one by one while ask. For example: What is this? this is a paint.

b. Guided dialogue, namely the Teacher gives a question and answer exercise. For example: are you going to ... this afternoon?, then the student answers, namely No, I am sleeping this afternoon.

c. Dramatic Actions, for example: What are you doing? I am sleeping.

d. Question and Answer Technique, namely the teacher must first determine the basic material of the lesson includes structure and vocabulary.

e. Explain sentences, paragraphs or short stories, for example the teacher tells stories, "my sister likes going to ... "then the student continues with the appropriate answer.

2. Communicative Activities

Communicative activities present several things, including:

a. Group conversations

The teacher's technique divides students into several groups. The students take turns to say something and then be joined by a group of friends so that it becomes a whole story.

b. Role Play

In this activity the teacher gives certain role assignments that must be done by students. The role that is in give must be adjusted to the level of mastery of the student language with the role card given. The goal is to:

- Practice of fluency in speaking

- Extend the use of languag

- Develop social interaction skills.

c. Practice social expressions 
Social expression means social behaviors when communicating that are expressed in a manner that respectfully compliments praise, congratulations, routines, asking permission and others.

d. Memory Games

This game requires children to repeat a certain sentence structure or word, such as 'I go to the market and buy ...' and students answer with the appropriate answers. The goal:

- To develop memory skills

- Practice pronunciation.

\subsection{Media in Teaching Speaking}

The function of using media is meaningful and clear for the students. Teaching and leaning methods are various. The students become more creative to do various activities, for example, creating an interesting learning atmosphere and solving limited space which increase students' motivation. Students develop based on their interest and speed conveying direct interaction with the environment, and having the same experience. Smaldino et al (2007: 12) explains five roles of media in learning as follows:

\section{Thematic Instruction}

Thematic instruction is known as the teachers' ways on organizing their instructions around topics. Elementary teachers in particular are integrating content and skills from many subjects. At the secondary level, teams of teachers from different content areas are working together to show the overlap of their course content. These units provide a rich environment of focus within which learning takes place. A good theme must capture and hold students' attention, provide problem solving experiences, support interdisciplinary activities, and include a variety of media and technology. 


\section{Portfolios}

A portfolio is a collection of students' work that illustrates growth over a period of time. Portfolios often include such artifacts as students-produced illustrated books, videos and computer multimedia projects. Students' ability to prepare mediated presentations that summarize their own understandings of thematic topic is central to the schooling experience under the concept of portfolios.

\section{Distance Education}

A rapidly developing approach to instruction worldwide is known as distance education. The distinguishing characteristic of distance education is the separation of the instructional team and students during learning. As a consequence, the course content must be delivered by instructional media.

Based on the discussion above the media serve many functions in the teaching and learning process. Media are not only able to be the teacher's language but also to help add elements of reality and motivate the students by bringing the slice of real life into the classroom. Besides, media provide clear context, meaning and guidance that can make students enthusiastic in learning English. Therefore, it is clear that media are very useful and really needed for the teaching and learning process.

4. Instructor-directed learning

A common use of media in an instructional situation is for supplemental support of the "live' instructor in the classroom. Certainly, properly designed media can enhance and promote learning and support teacher-based instruction. Advance organized 
can be effective instruments for ensuring that media play their proper role as supplemental supporters of instructions.

\section{Learner-directed learning}

Media can also be used effectively in formal education situations where a teacher is not available or is working with other students. Media are often "packaged" for this purpose; objectives are listed, guidance in achieving objectives is given, materials are assembled, and self evaluation guidelines are provided.

Based on the discussion above, it can be concluded that media play an important role in the teaching and learning of English. Media are not only able to be the teacher's language but also to help add elements of reality and motivate the students by bringing the slice of real life into the classroom. Besides, media provide clear context, meaning and guidance that can make students enthusiastic in learning English. It is clear stated that media are very useful and really needed for the teaching and learning process.

There are various kinds of media that can be used in the teaching and learning process. Teachers should know what kind of media those are appropriate to the students in the teaching and learning process. According to Smaldino et al (2007), there are six kinds of media: text, audio, visuals, video, manipulative and people. However, the researcher chooses videos as media in the teaching and learning process. The use of videos in the teaching and learning process can be more communicative than long explanation, or it can supplement the teacher's explanation. Besides, videos can make students motivated and attracted to the teaching and learning process. 


\subsection{Reading}

Reading is a process done and used by readers to obtain a message, which is to be conveyed by the author through a word media or writing language (H.G. Tarigan, 1986:7). A process that demands that a group of words that constitute a unity will be seen in a glance, and so that the meaning of the word individually will be known. If this is not fulfilled, then the message expressed and implied will not be captured or understood, and the process of reading is not carried out either (Hodgson in Tarigan, 1986:7)

Reading is an activity to respond to written symbols using proper understanding (Ahmad S. Harjasujana in St. Y. Slamet, 2008:67). This means that reading responds to all expressions of the author so as to understand the reading material well. Other sources also reveal that reading is an act based on the cooperation of several skills, namely observing, understanding, and thinking (Jazir Burhan in St. Y. Slamet, 2008:67)

In short, it can be said that reading is bringing meaning to and getting meaning from printed or written material, picking and understanding the meaning or meaning of the sums in the written material (Finochiaro and Bonomo Daam H.G. Tarigan, 1986:8). The reading activity is a capture and understanding of ideas, a reading activity accompanied by a soul in the life of the manuscript. The reading process begins from the activity of mechanical activity and the sensory activities of the eye for normal, tactile tools for the blind. Once the process progresses, the reason and the Institute that Works is the process of understanding and passion. In addition, the reading activity also emphasizes adherence and speed also patterns of 
competence or language skills, certain intelligence and a broad referent of life.

From the sense of reading above, it can be concluded that the reading activity is to understand the content, ideas, or ideas either expressed or implied in the reading material. Thus, understanding becomes a measurable product after reading, not physical behavior at the time of reading. The facts or essence of reading is understanding (St. Y. Slamet, 2008:68).

\section{2 Aspects of reading}

Broadly, there are two important aspects of reading:

1. Mechanical Skills (mechanical skills) that can be considered as a lower order. These aspects include:

a. Letter shape recognition

b. Introduction of linguistic elements (phoneme/morphemes, words, phrases, patterns, clause, sentences etc; )

c. Slow-grade reading speed

2. Skills that are understanding (comprehension skills) that can be considered in higher order (higher order). These aspects include:

a. Understanding the simple sense (lexical, grammatical, rhetorical)

b. Understand the significance or meaning

c. Evaluation or assessment (content, form)

d. Flexible reading speed, which easily adapts to the circumstances (Broughton, 1978:211)

\subsection{Stages of reading activities}

1. Pre-reading activities

Activities undertaken before a person conducts a reading activity. It serves to inform the initial knowledge related to the aspects of 
reading that is to be understood. In addition, it can train students to know the purpose of reading, and to give motivation and confidence.

\section{Reading activities}

This activity is a key activity in the overall reading phase. An effective and efficient reader must first know the purpose of his reading. After knowing the purpose of reading, a reader would choose the right and appropriate reading strategy to achieve that goal.

\section{Post-Reading activities}

This activity is carried out after a reader conducts reading activities. It serves to check if what is read is well understood.

The basic developmental stages of reading in children aged 4-6 years are in five phases:

\section{- Magical Stage}

At this stage the child begins to learn using the book. The child begins to think that the book is important by flipping through books

- Self Concept Stage

The child sees himself as a reader and begins to involve himself in a reading activity, pretending to read the book

- Bridging Read Stage

The child realizes the visible mold and starts to find the familiar word

- Take-off reader stage 
The child begins using three cue systems (Graphoponic, semantic, and syntactic) together. The child starts to be interested in reading and begins to read the signs that are in the environment such as reading cardboard milk, toothpaste, etc.

- Independent reader stage

Children can read different types of books freely. Letters and words are an abstract for children, so to identify them the teacher must make them become real by associating the things that are easy for the child to remember. First time, the letters are usually used to concentrate only on the initial letters of a word already known to the child. And in order that there is no sense of coercion "learning to read" in children it should be done with fun.

\subsection{Types for reading}

There are two types of teaching reading; Extensive and intensive. Extensive and intensive differ in some cases. The first difference is that extensive reading covers a large area, while intensive reading covers a narrower area. According to Graham Stanley, extensive reading involves students reading long texts or large numbers for common understanding, with the intent of enjoying the text. This means that students are given the freedom to choose their own topics that they think are interested in discussing. In this case, students should also find supported articles related to the topic to give them background knowledge, so they know more about the topic they choose. Different from intensive reading that does not allow students to discover topics they like. Topics given by teachers. Students also don't need to search for supporting articles because the topics chosen by the teacher are usually short and easy to understand. 
The second difference is about student activity in the classroom. In Extensive reading of student activity is more complex than in intensive reading. The students, in the extensive reading class, are usually asked to write a summary after reading the article/section. As we know, writing summaries is not an easy thing to do. This allows learners to assert full control, whether the main factual or fictional content of an article/book, and the grammar and vocabulary used to express it (Bell, 1998). In addition, students will also do a short presentation of what they have read. By doing a short presentation, students will have the knowledge of proper preparation, independence and autonomy (Bell, 1998). While in Intensive Reading, instead of writing summaries and presenting, students were asked to answer a few questions related to the topic given by the teacher. Usually, all answers are available in the text, so students only rewrite.

Lastly, Extensive Reading will prevent the use of excessive dictionaries (Bell, 1998);Otherwise dictionaries are a must in intensive reading. It is true that dictionaries have an important place in the reading activity, but as stated by Bell (1998) that students will focus only on language if they always consult with a dictionary whenever they find an unknown word. They will not pay attention to the message delivered. Bell (1998) also says that this habit will cause inefficient readings and destroy the pleasures intended by readings. Graham Stanley of the British Council, Barcelona said that by avoiding dictionaries, students are expected to be encouraged to write down words they encounter in vocabulary notebooks and they can look after them after they have finished reading. This will make students guess meaning based on context. By doing this, students can always remember the meaning of a word because they found it themselves. In the meantime in Intensive Reading, students must find difficult words when they are reading. The frequency of using dictionaries often because it is in intensive reading, a text will be used to answer 
a few questions, so students should know the meaning of all the words in the text to make it easy to answer questions.

\subsection{Teaching Reading}

First, while teaching reading, teachers should not force students to read quickly. But the teacher should emphasize the accuracy (pronunciation). How do we pronounce a word in English properly and correctly.

Secondly, while teaching reading, teachers must ask for no more than one student to read at the same time. That is, it is not good to invite more than one student to read together. In addition, teachers should also pay attention to each student in the classroom.

Third, when teaching reading, teachers must be careful in telling and reciting mistakes in pronunciation or pronunciations, articulation, and intonation of students in reading.

Fourth, while teaching reading, teachers must first try to know the reasons for the mistakes that the students performed and try to justify the mistakes by eliminating the cause of the mistake.

Fifth, when teaching reading, teachers should care about the right way of sitting in the reading (Bergeron and Bradburry, 2002). 


\subsection{Methods in Teaching Reading}

Then the reading process is divided into:

\section{Classical Reading}

That is the reading done jointly in a class. Classical reading is usually carried out in class. With the aim that the child who has not been able to read can imitate it first.

\section{Read groups}

A reading that is done by a group of students in a class. Usually done in line. One series is used as a group. By reading the group of teachers can pay attention to more serious (specifically) children who have been fluent reading or who have not been fluent in reading. For children who have not been fluent reading usually tend to be silent (not impersonate).

\section{Individual reading}

That is, the individual reading. Individual reading required The students' courage and easily controlled by the teacher. Usually conducted to conduct assessments

\section{Read silently}

Reading silently is read by not issuing words or voices. By reading in the hearts of students can concentrate more, so that more can understand the contents contained in a reading. Reading silently actually reads for adults or parents. Not all elementary students can be read on silently. Reading silently of elementary school students is done by reading aloud or reading whispering. Cannot be performed perfectly. Special class I and class II have no learning to read silently. Class III-IV can be trained reading with the voice of whispering. While the $\mathrm{V}-\mathrm{VI}$ class can be read on silently is better. 
The purpose of reading is silently so that students can:
A. Concentrating physically and mentally
B. Fast reading
C. Understand the content
D. Internalize content
E. Expressing reading content

According to the concept of language learning and the level of development of elementary school children as outlined in the above sections, here are presented several methods of learning English relevant to elementary level.

\section{A. The Reading Method}

The Reading method emphasizes reading as a key activity in learning English. In the early stages, it is read aloud with the aim of practicing speech. Loud reading is very important for elementary school children familiarize themselves with their English sounding instruments. In the early stages, reading is also very beneficial to develop students ' vocabulary. Reading comprehension may be given, but at a low level of difficulty.

\section{B. Songs and Games}

Games and songs can have two important functions in English language learning. Firstly, a wide variety of games and songs can be used to teach English, such as vocabulary, pronunciation, and fluency. Secondly, games and songs can be introduced to the society and Culture of English-speaking users as the first language. Some examples of games and songs are given specifically for the provisions of the teachers in Bangli teaching English in elementary school. 


\section{Field Study}

The best Media for learning is a straightforward object. Teachers need to bring students to study in the real world, where they are. There students learned English from objects and life around it. Judging from this point of view, the best thing that teachers can do to invite students to learn authentically and meaningfully is to provide a language rich environment.

\subsection{Media in Teaching Reading}

\section{White Board}

A whiteboard has a smooth glossy white surface, which can be written: with a special pen or marker that is colourful and easily removed.

You will need

- Special thick chalkboard pen with ink can be removed

- Sponge or Erasers to clear the board. The whiteboard can be used in the same way as whiteboards for writing or drawing. At first it will probably get the difficulty of keeping the horizontal writing, and the same size and style, so you will need to practice.

Before writing on the board in the learning process in class, make a summary of the lesson plan to make it easier for you to be in the classroom. At least we already know what we're going to write or draw in the class. This should be clear and well arranged. Bar graphs, line graphs, pie charts and diagrams can be drawn on the board before the lesson begins. 


\section{Poster}

"Posters a display device is designed to attract attention and communicate stories, facts, ideas, or images quickly and clearly. "Good Dictionary education: A Poster is a" plaque, usually illustrated or decorative, utilizing the emotional appeal to convey a message aimed at strengthening attitudes or urgent action ". For English learning the use of posters can strengthen students ' understanding of a material.

Posters can be defined as a graphical representation of some strong emotional appeal that is performed through a combination of graphical aids such as images, cartoon letters and other visual arts on placards. It aims to convey certain messages, teach certain things, give a general picture, etc. Posters have had a great influence on students ' understanding of the class.

\section{Flash card}

Flashcards are small cards with pictures or symbols used on them both in teaching and in development work. In the classroom, flash cards are usually used to teach "Vocabulary" or "Reading".

An image, for example, an elephant can be pulled or stuck on a card and word

'Elephant ' written underneath or on different cards. The students are encouraged to associate pictures and words through the various' look and say ' activities and games, for example, Kim games, couples, and so on. 
In teaching and development, flashcards may have a symbol image drawn or painted on them. They are very useful for stimulating discussions in small groups, as well as for sharing information and reminding people of the recommended process with posters, local situation research and pre-test them.

How to use flashcards:

To use flashcards in class situations, such as learning to read shows pictures and words together. Ask students to look at pictures and pronounce words. Then they see the word and say it again. After presenting a number of words with pictures that students already know, ask volunteers to get out and match the pictures and words.

\section{Crossword Puzzle}

Crossword Puzzle is a learning media that involves the participation of active learners in learning. Learners are invited to participate in the learning process, as well as mental and physical events. Learners will feel a more enjoyable atmosphere so that learning results can be maximized. In addition, Crossword Puzzle can be used to review or recall material that has been submitted.

Crossword Puzzle is a rectangular pattern consisting of squares that are black and white, and has rows and columns that are flat and downhill. The function of the crossword puzzles itself gives the effect of refreshing memory so that the brain work is optimised again because the brain is used to continuously learn casually. Because this casual learning can make learners more understanding and easy to remember with the material that has been taught. The advantages of Crossword Puzzle media are simpler to teach, and train thoroughness or clarity to answer questions and hone the brain. 
In English learning, students are as closely involved as they can be active during the learning process. The use of crossword puzzle media can create that activity. Considering this type of media has the characteristics of a game that is easy and enjoyable to have a high sense of curiosity, according to the development of learners who are generally pleased to play. Students become enthusiastic independently and in groups.

English lessons are often blackened as difficult lessons, causing many learners to feel allergic in the course of learning, and only those with more intelligence who are interested in this lesson. However, by using crossword puzzle learning materials can be learned with fun and not boring.

Crossword Puzzle is suitable for learning theories or concepts that are not calculations or numbers, for example in physics subjects about the solar system. Learning the Solar system with theory is certainly harder than learning the traits of living creatures.

To be able to learn without difficulty, learning techniques with Crossword Puzzle Games is one of the solutions. The process of presenting the media, according to:

1. Determine the subject.

2. Crafting Crossword Puzzle covers the items obtained.

3. Presenting to groups or individuals.

4. Fill rules According to number of characters.

5. Specify the duration. 
6. Give gifts to the most fast and correct. Crossword puzzle making is not difficult, especially in the process of using computer media/notebooks, but it takes patience and thoroughness.

With the crossword puzzle media, hopefully it can motivate teachers to create breakthroughs in creating creative and innovative learning media. So it is useful in the world of education and not only focus on the media of electronic goods or modern goods, but an equipment can be used as an effective medium.

\section{Story Book}

Learning media with a "story book" is a learning English language, which on this media like a module, but made more interesting to look attractive and make students happy and interested in learning. 


\section{CHAPTER IV TEACHING WRITING}

\subsection{Definition of Writing}

A language is used for many kinds of purposes. Thus, it has many functions as well. Furthermore, there are two macro skills of a language; they are receptive and productive skills. Writing skill is one of the productive skills that should be mastered in using a language. It is because writing skill has significances in improving a communicative competence of learning the language.

Students learn and acquire language through both written and spoken ways so that they can improve their communicative competence. In the process of communication, ideally students know the rules on how to communicate to others, how to get information, and how to communicate about the language itself. When the students understand the knowledge of the language, it means that they have a language competence. In line with this, Brown (2000: 31) states the definition of a language competence as "one's underlying knowledge of system of a language - its rules of grammar, its vocabulary, and all the pieces of language and how those pieces fit together". Furthermore, Bachman (1990: 87) divides the language competence into two parts: organization competence and pragmatic competence. Organization competence is ability to comprehend and form correct sentences, understand meaning of sentences and pour 
theses sentences into a text. Based on this statement, it can be concluded that writing is one part of the competencies.

The definitions of writing are variously stated by some experts. According to Rivers (1981: 294), writing is conveying information or expression of original ideas in a consecutive way in the new language. Brown, (2001: 336) also claimed that writing is a thinking process. Furthermore, he states that writing can be planned and given with an unlimited number of revisions before its release. In addition, Elbow (1973) in Brown (2001: 336) also says that writing is a two-step process. The first process is figuring out the meaning and the second process is putting the meaning into language. Writing represents what we think. It is because the writing process reflects things, which stay in the mind. Students who are reluctant to write things down often suffer for this activity. The students find difficulties when they start looking for some reasons to write and producing written sentences.

Another definition of writing skill is also defined by Urquhart and Mclver and also Harmer. Urquhart and Mclver (2005: 5-6) state that writing is a recursive process, which means students revise throughout the process, frequently moving back and forth among the stages. Then, students should learn strategies for invention and discovery, and teachers should help students generate content and discover a purpose. Also, it is stated that readers, purpose, and 
occasion define all types of writing and effective writing fulfills the writer's intention and meets the readers' needs. It means that writing is a complex process and it seems reasonable to expect, then, that the teaching of writing is complex as well. Moreover, Harmer (2004) states that writing encourages students to focus on accurate language use. It is because students consider the language use when the students engage in their writing process. This activity will provoke language development because the students resolve problems what writing puts in students' minds.

Based on the definitions above, a definition of writing skill can be obtained. Writing is a productive process done through some stages. Firstly, exploring and transmitting ideas, thought and feeling into written form. Secondly, conducting a number of revising process to carry out a grammatically and orderly texts. The writing productions are in the forms of readable texts which should be meaningful to everyone who read the writing.

Furthermore, based on those definitions, it can be stated that writing skill is a complex activity in producing a qualified writing. The complex activity consists of stages as the steps in writing. To improve students' writing skill, the teaching and learning process of writing needs to be done well with developed input and effective activities. As a result, teachers need to consider the teaching of writing skill well based on their student's needs, ability and capacity. 


\subsection{The Characteristics of Writing}

There are 8 characteristics of writing skill:

1. Permanents, it means that the form of discourse is fixed and stable, we however can read it in any condition we want to.

2. Explicit, it means that those must be clarity about the context and reference. The writer must be careful for arranging the form of words, so readers are directed to the same interpretation about the written work.

3. Densities, the information that will be given to the reader are translated effectively. The use of repetition words are rarely found in the written form. It is very different to spoken language.

4. Detachment, the writer must have an ability to predict their readers reaction about their writing, because the writer doesnot interact directly to the reader.

5. Organization, the writer usually has an opportunity to edit the written work before it is available to be read. So the written work tends to be organized and well purposed.

6. Slowing of production, speed and reception are slower than spoken.

7. Standard Language, it is usually acceptable for a varied language.

8. A learnt skill, it must be learnt and thought to acquire the skill.

\subsection{Methods in Teaching Writing}

Writing skill is one of language skills which are taught to students. Also, writing skill determine the students' communicative competence in English. According to BSNP (2006), communicative competences are having discourse abilities; they are comprehending 
oral and written texts and producing oral and written texts. Those abilities are carried out into four language skills, listening, speaking, reading and writing.

The teaching of writing skill has some objectives and indicators. It is stated in BSNP 2006 that the teaching and learning of writing skill in Junior High School is targeted to achieve a functional level. On the functional level, students are able to communicate adequately both in the spoken and written form to complete daily activities. Moreover, students are able to create some monologue short functional texts and essays in the form of procedure, descriptive, recount, narrative, and report. The other target on the functional level is students can develop their linguistic competence (using grammar and vocabularies).

A writing process is a complicated process, because the writing process needs cognitive abilities in recognizing some segments of languages to produce a qualified writing. In general, writing process is done through two stages: exploring ideas and processing the ideas into readable texts. Rivers (1981: 294) claimed that writing in the language becomes a complicated activity because writing involves meaningful segments of language: words, sentence, grammar, and how to transfer those segments into written forms.

Mc Crimmon explained that there are three essential steps of the writing process, namely: 
- Planning,

Planning is also pre-writing. In this step, the students are expected to be able to formulate the purpose, then organize the message. Selecting something to write is needed, because most of the students often spend their time before doing activities. It is better for them to make planning in order to write easily. In the pre-writing step, the students begin to dig for the basic raw materials that they need. After that, they must look into their mind about the subject that becomes a topic because selecting the topic is very important for giving the first description of what to write. In the pre-writing, the learners have many kinds of ideas. They only concern to find subject that is going to write.

- Drafting

Drafting is procedure for determining whether the ideas which have been discovered during planning that can be formed into a successful piece of writing. It enables the students to have experiment with possible arrangements of one topic. In this stage, the students have to examine the ideas, arrange, and rearrange them in order to form them into a coherent first draft. The first draft is also called discovery draft because the learners will discover something that new about the subject, audience, and purpose. The discoveries will help the students to learn about what they want to say and how will they say it. 
After that, the students construct a formal outline. The formal outline is an exact plan of organization that breaks the topic into major units and subdivides these major units into minor units. The best way to construct the formal outline is to layout the major divisions before worrying about the various subdivisions. Besides, examining the formal outline, the students should revise it.

- Revising

The last step in writing is revising. Revising is the process of checking again, or discovering a new division for the writing the student produce during planning and drafting. There are two steps in revising:

a. The students should employ various reading strategies to help them rethink, reorder, and rewrite substantial portions of what they have been written.

b. The students should fix the sentences, phrases, and words.

Objectives of the teaching of writing skill can be achieved through some approaches. According to Harmer (2001: 25), there are two approaches in teaching writing. They are focusing on the product of writing process and focusing on the writing process itself. He states that focusing on the writing process leads those who advocate a 
process approach in writing. However, teachers have to pay attention to the various stages of any piece of writing process.

The writing approaches, including a process approach, are applied to get the objectives of study in writing skill; they are enabling the students to understand the materials and helping them to express their ideas grammatically and orderly in English. In addition, Nunan (1989: 36) says that a process approach in writing sees the act of composition from a different perspective, or focusing as much on itself. He also states that the process approach focuses on the steps involving drafting and redrafting a piece of work. In other words, on this process approach, the important one is not only in the product, but also in the writing process. Therefore, the process approach can be developed through writing practices routinely with effective activities also a better input to improve the students' writing skill.

A writing process is done through some stages. On each stage, students engage in a certain activity to construct their writing. Furthermore, Richard and Renandya (2002: 303) state that the process of writing consists of planning, drafting, revising and editing. On the planning stage, the students are encouraged to write. The drafting stage is focusing on the fluency of writing and is not pre occupied with grammatical accuracy or the neatness of the draft. Next, on the revising stage, the students re-write their text on the basis of feedback given in a responding stage. The students, on the 
editing stage, are engaged in tidying up their texts as they prepare the final draft for evaluation by the teachers.

\subsection{Types of Writing}

Types of writing activities to perform writing should be based on the students' level and capacity. According to Brown (2001: 343), there are five major categories of classroom writing performance:

1. Imitative, or writing down

This type is at the beginning level of learning to write. Students will simply write down English letter, words, and possibly sentences in order to learn the conventions of the orthographic code.

2. Intensive, or controlled

This intensive writing typically appears in controlled, written grammar exercises. This type of writing does not allow much creativity on the part of the writer. A controlled writing is to present in which the students have to alter a given structure through out.

3. Self-writing

The most salient instance of this category in classroom is note-taking by the students. Diary or journal writing also falls into this category.

4. Display writing

For all language students, short answer exercises, essay examinations and research reports will involve an element of display. 
One of the academic skills of ESL students that they need to master is a whole array of display writing techniques.

5. Real Writing

Some classroom writing aims at the genuine communication of messages to an audience in need of those messages.

According to the theories above, the teaching of writing skill should be well constructed. Those types of writing activities that will be applied in teaching writing are based on the students' level and capacity. Also, the writing practices, including writing paragraphs or simple essays should be based on the standards of competence and the basic competencies. Those efforts above should be done well to improve the students' writing skill.

\subsection{Media in Teaching Writing}

Media play many roles in transmitting materials to students and support to create an effective and efficient learning process, including the learning of writing skill. According to Smaldino, Lowther, and Russell (2008: 6), media, the plural form of medium, are means of communication. In addition, they state that media are anything that carries information between a source and a receiver. It means that in teaching and learning process, teachers can explain the materials using the learning media in a more concrete way. In line with this, Newby, Stepich, Lehman, Russell (2000: 100) state that 
media can serve or facilitate student learning process. Furthermore, they state that media can provide a stimulus-rich environment because they can provide vicarious experiences for students. Based on the statements, it can be stated that media are everything that can transmit learning materials from the sources based on a certain plan in order to create a helpful learning process so that the receivers can learn effectively and efficiently.

There are three kinds of media that can be used in teaching writing skill. 1) Visual, for example: pictures and photos. 2) Audio, for example: tape recorder, cassettes, and radio. 3) Audiovisual, for example: movies, and videos. Smaldino, Lowther, and Russell (2008: 6) classify media into six basic categories: (1) Text, is alphanumeric characters that may be displayed in any format, for example: book, poster and so on. (2) Audio, includes anything that can be heard and it may be live or recorded, for example: teacher's voices, music and mechanical sounds. (3) Visuals, are regularly used to promote learning, for example: cartoons and photographs. (4) Audiovisual / Video, shows motion, for example: movies, DVDs and computer animation. (5) Manipulatives, are three dimensional and can be touched and handled by students. (6) People, for example: teachers, and students. All kinds of media can be utilized, if the media are relevant to the materials and effective to support the teaching of writing skill. 
Some of the instructional media above can be utilized to support the effective teaching of writing skill. Related to this, Onasanya (2004) states that plethora of media offers teachers considerable opportunities to make their teaching more effective and efficient. Also she states that the effectiveness in the context implies how well educational goals and objectives are achieved, while the efficiency refers to how instructional media are utilized to achieve teaching goals and objectives. Therefore, the teachers need to consider appropriate media in order to stimulate students to explore their ideas to help them in their writing process and make the students understand the learning materials given by the teacher effectively.

It is also urgent for teachers to know functions of media in a learning process well. This attempt will help the teachers to select relevant and effective media that can be used to teach writing. Erdmenger (1997: 6) states that the functions of media that are used in a teaching process, including teaching writing include:

- arousing the students' motivation,

- transmitting information, - directing the students by giving clues of the materials which are taught,

- controlling the objectives of the study by helping the students to focus on the materials which are taught. 
The functions of media in a learning process are also stated by Munadi (2008: 36-48). He states that learning media have some functions:

1. Learning media as a learning resource.

2. Learning media as a semantic function; the media can help the students easily understand the materials easily.

3. Learning media as a manipulative function; the media avoid the borders of space and time and the limitation of senses.

4. Learning media as a psychological function.

5. Learning media as a socio-cultural function; the media avoid constraints among students in a learning process.

In teaching writing skill, the teachers need to use media that can motivate and help the students understand the materials. Anderson (1987) in Sadiman (2003: 96-99) states that cognitive and affective learning processes need to have moves, color, sounds stimulus, and interactions with other things. Related to this, learning processes, including the learning of writing, need to use appropriate media, for example: movies and videos. This is because movies and videos can present moves, sounds, and interactions. Besides, the use of those media is suitable to students who always have curiosity to something new, attractive, and modern. Consequently, the use of 
media in learning writing should be improved to arouse the students' motivation and help them develop their writing skill.

Based on the explanations above, some kinds of media, including audio visual media for example, movies and videos, can be utilized as media for teaching writing. Through the use of these media, the students may get benefits in their writing processes. This is because the media support the learning of writing effectively and help to transmit the materials given by the teachers to the students. However, the use of media needs to be selected properly in order to be effective and relevant to the objectives of the study.

\subsection{Effective Media for Teaching Writing}

There are many examples of media that can be used in teaching of writing skill, as media are various in types and functions. Besides, it has been known that the use of media in learning writing needs to be improved to obtain learning goals. As a result, teachers need to select appropriate media in order to maintain students' writing process effectively.

The teaching and learning process of writing skill should be done effectively to achieve the objectives in learning writing. Based 
on a dual coding hypothesis by Paivio (1978) in Arsyad (1997: 6), there are two human memorizing systems. The first system manages verbal symbols and saves in the form of image proposition. The second system manages nonverbal images and saves them into verbal proposition. In other words, learning by using two senses; visual and audio sense will give an advantage. The students will learn materials more extensively than learn materials which are transmitted through one sense, either audio or visual.

Media which present visual and audio senses are audiovisual media. According to Arsyad (1997: 30), audiovisual media or technology are things that are used to produce or transmit materials using mechanics and electronics to present audio messages and visual messages. Besides, Newby, Stepich, Lehman, and Russell (2000: 100) state that audiovisual media present moving images that can be recorded on videotape, videodisc, DVD and computer disk. All these formats offer ways to store and display moving images accompanied by sound. Related to this, the information from audiovisual media will be captured more easily by the students. Therefore, the teaching of writing skill can be done by using audiovisual media, for example: movies, television, and videos. The students can be asked to rewrite a story of a displayed movie or video.

The use of effective media will support an effective teaching and learning process of writing. Rijlaarsdam and Van Den Bergh (2005: 
6) state that an effective writing requires that students play different roles. First, they must be in a position to experience communication; it means that the students as the writer experience the effects of written and spoken communication. Reflecting on this statement, the use of movies helps students experience a communication when they experience the effects of written and spoken communication. The students in their pre-writing stages will experience how texts from movies affect them as the readers and listeners. Then, the students may also experience texts and formulate their responses.

The use of movie, which also presents oral speech in teaching writing, can be effective to facilitate the students in their writing process to generate contents and focus on what they are learning. In line with this, Rijlaarsdam and Van Den Bergh (2005: 10) state that oral skills and writing are connected to focus on scaffolding content generation and collaborative work where oral speech facilitates writing and awareness rising. The relation among the communicative modes is a means-end relation in most instances: oral activities contribute to content generation or awareness raising; reading facilitates the acquistion of genre knowledge, reader awareness, awareness of coherence etc.

The teaching of writing skill needs to use audiovisual media (movies, videos) because audiovisual media are the unification of visualization, audio, and moves that can present objects, events, and 
places. All of those aspects are necessary in a writing process. Besides, movies (audiovisual media) will attract the students' motivation better than conventional media and invite the students' arguments or feedback based on the movie story. Related to this, Champoux (2003) claimed that the visual and audio effects of movies can convey a message better than printed or spoken words. He stated that movies offer both cognitive and affective experiences because movies can provoke good discussions, assessments of one's values, and assessments of a self if the scenes have strong emotional content.

Harmer (2001: 282) explains some reason why the use of videos (movies) is needed in the teaching and learning process. He states that the use of videos (movies) can add a special or extra dimension to the learning experience. The first reason is seeing language-in-use, the students do not just hear language, but they see it too. The second reason is cross-cultural awareness; it allows students look at situations far beyond their classrooms. The third reason is the power of creation; students are given the potential to create something memorable and enjoyable. The last reason is motivation, most students show an increased level of interest when they have a chance to see language in use as well as hear it, and when this is coupled with interesting tasks.

The use of movies can be done through several ways. Movies can be displayed at the beginning of the session of writing class. By 
this, students can grab some inspirations after watching the movie. It stimulates the students to write grammatical and order texts. However, it may take a longer time for some students to compose the content orderly and grammatically. Furthermore, Champoux (2003) states that movies are widely available and easily accessed as learning resources. As a result, the use of movies will be easily utilized to give positive effects in writing processes for the students.

Based on some considerations in selecting effective media for writing above, some kinds of movies can be used to help the students write texts grammatically and orderly in their writing process. In line with this, Onasanya (2004) states that media that are used by a teacher should be considered in terms of concreteness or abstractness of experience that is produced by the media. She also states that teachers should be sensitive to the changing situation within the classroom and have alternative media to meet individual differences of the students. Regarding to this, selecting media to teach writing is very important. The use of movies can be appropriate media to be utilized in teaching writing because movies can present concreteness or abstractness of experience to motivate the students in their writing process.

By using movies in learning writing, the students will find an effective but enjoyable learning while and after watching the movies. This situation will maintain the students to start writing. Also, 
watching movies can reduce the number of grammatical errors and improve the quality of the writing content, because movies give the students much inspiration to write. Displaying movies at classes is expected to give many benefits to students not only writing the content grammatically and orderly but also improving and mastering the vocabulary through its subtitles and audios. Harmer (2001: 258259) states that writing processes can be developed through a genre approach. Students are given many inputs in a certain genre in their prewriting phase. In addition, students who are writing within a certain genre need to consider a number of different factors: knowledge of the topic, the conventions, the style of the genre, and the context. Related to this, it can be concluded that the teaching writing based on genres can help the students in their writing process, as it is easier when the students are asked to write a certain type of the genre. Also the students' writing process will be more guided and clearer.

By watching movies, the students can understand materials easier because the movies can present a certain genre to study. Hesitation and misunderstanding about the materials can be minimized significantly. Movies as audiovisual media can maintain inspirations and motivations to enhance creativities in expressing ideas into writing. In addition, the students can study certain text types through movie stories which present certain genres and 
encourage the students to make a guided writing based on questions related to the movie story.

Based on the theories above, the use of movies as audiovisual media in teaching writing can be effective to get the objectives of the study. This is supported by Uma and Ponambala (2001) who state that movies can be an effective tool, because the media can lend itself freely for distance teaching and learning, including writing skill that can be taught through a distance mode. Moreover, the use of movie that presents visual senses, audio senses, and genres will transmit the materials effectively and stimulate the students in exploring and expressing ideas in the writing process. However, teachers must select movies appropriately so that they are relevantly related to the materials which are taught and the levels of the students.

\subsection{Difficulties in Writing English}

Like all learning problems, difficulties in writing can be devastating to a student's education. Heaton (1975) stated that writing skill is complex and sometimes it is difficult to teach. Requiring mastery are not only of grammatical and rhetorical devices but also of conceptual and judgmental elements. As students' progress, they are increasingly expected to express what they know about many different subjects through writing. If a student fails to develop certain basic skills, he will be unable to write with the speed and fluency required to excel as these demands increase. Indeed, for a student's struggling with a writing problem, the writing process itself interferes with learning. Students faced with such difficult odds have trouble staying motivated.

The basic point that makes writing difficult is the use of language aspect or ability in written likes punctuation, spelling, 
grammatical, vocabulary and so on. According to Jordan (1997), writing is often confusing with the process of putting words down on paper in the same structure as an outline prepared with appropriate style and vocabulary the major ideas arranged in some often on the correction of mechanical and grammatical errors.

Bryne (1988) divided the problems that make writing difficult into three categories:

- $\quad$ The first is Linguistic Difficulty. Linguistics aspect like grammar, vocabulary, language use and choice of sentence in writing must have fully monitoring.

- The second is Physiology Difficulty, which more focuses on the writer's difficulty because there are not direct interaction and feedback from the reader when they are writing. This difficulty more focuses on difficulty in develop written material or content of composition.

- The third is cognitive difficulty. Writing has to be thought through formal instruction like spelling, punctuation, capitalization and paragraphing.

\subsection{The Principles of Good Materials}

To design effective materials, it is important to know the principles of good materials. The principles of good materials can be used as a guideline in designing the effective learning materials. Tomlinson (1998: 7-21) suggests some principles of the good learning materials. The principles of the good learning materials are stated as follow.

1. Materials should achieve impact. Impact will be achieved when these are effect on the learners. The effect can be noticed from 
the learners' curiosity, attraction, intention and interest in the materials.

2. Materials should help learner to feel ease. Materials should make the learners feel comfortable.

3. Materials should help learners to develop confidence. It is very important to increase the students' confidence because if the students have been confident, they will be easy in learning something.

4. What is being taught should be perceived by learners as relevant and useful. Materials should provide information that is needed by the learners.

5. Materials should provide the learners with the opportunities to use the target language to achieve communicative purpose. Good materials should facilitate learners' interaction by providing appropriate activities.

6. Materials should not rely too much on controlled practice. The materials should be arranged in balance, form guided to free production practice.

In line with Tomlinson, Hutchinson and Waters (1987: 107108 ) also identify six principles in writing the good materials. The first principle is that materials should encourage learners to learn. Therefore, the materials should contain interesting text, enjoyable activities which engage the learners' thinking capacities and opportunities for learners to use their existing knowledge and skills and content which both learner and teacher can cope with. The second principle is materials help to organize the teaching-learning process. Good materials should provide a clear and coherent unit structure which will guide teacher and learner through various. The 
third principle is materials embody a view of the nature language and learning. Materials should reflect what you think and feel about the learning process. The fourth principle is materials reflect the nature of the learning task. The fifth principle is materials can wider the basis of teacher training by introducing teachers to new techniques. The last principle is materials provide models of correct and appropriate language use. 


\section{CHAPTER V ASSESSING ENGLISH IN YOUNG}

\section{LEARNERS}

\subsection{What is Assessment?}

Assessment occurs all the time. Assessment is the gathering of information for a specific purposes. When you go to bookstore and select a book to read, you make an assessment as to which book will provide you with information or pleasure. The process is so automatic that you are probably unaware that assessment is part of it. There are other times when assessment, is more conscious, such as a making a decision as to which job to take or university to apply to.

Assessment differs from evaluation. It can be useful to look at the distinction between the two. Assessment refers to collecting information and making judgements on a learner's knowledge, whereas evaluation is need when collecting and interpreting information for making decisions about the effectiveness of an education program (Brindley, 2003).

When we think of assessment, we usually think of teachers using it to determine how well an individual child or a group of children are doing. As a teacher, it is important to have clear instructional goals so that you can assess whether the goals have been met (Cameron, 2001). If you don't know your aims and purposes in teaching, you won't be able to determine whether they have been achieved. Assessment should reflect specific program objectives that are representatives of the overall-program goals.

Assessment practice should also reflect the instructional practices in place (Georgiou-lannou and Pavlou, 2003). If you are teaching using an approach that takes into account the 
developmental needs of your students, then your assessment procedures should also take into account their developmental needs. Unfortunately, there may instances when the assessment is mandated by local or even national officials and does not correspond with the instructional practice used in the classroom.

When assessing students, it's important to remember that assessment should be measure of what students are able to do and what they know, rather than measures of what they are not able to do and do not know (Freeman and Freeman, 2004). The emphasis should be on the skills and knowledge that students have acquired within the context of their development and cultural heritage. Assessment should help you better understand what additional skills your students need to acquire. Assessment should not just be another item on an educational "must do" list but rather should serve a real purpose ranging from initial placement to program monitoring (Brindley, 2003)

Assessment is different from evaluation. As mention above, assessment looks at what individuals and groups of learners can do. Evaluation, on the other hand, concerns an entire educational program and not just specific learners and is much wider scope (Brindley, 2003). Much of the information you obtain from classroom assessment can, and should be, apart of a program evaluation. Then when an English-language program is evaluated, effective changes can be made to improve the overall quality of the classroom.

Two concepts are important when discussing assessment. They are validity and reliability. An assessment is considered to have validity if it measures the skill it is supposed to measure with a specific group of learners. When looking to see if an assessment activity is 
valid, you need to look at what the activity is and what is it supposed to measure.

When examining test validity, it is also important to determine whether the assessment is valid for the learners who will be taking the test. For instance, test items that are valid for young learners in large urban areas may not be valid for children living in rural areas. Another example would be a test which is valid for beginning learners who are 12 and 13 years old may not valid for children who are five or six year olds.

After examining an assessment tool's validity, you should look at its reliability. An assessment tool is reliable if the results are consistent over a period of time. This means that for a test to have reliability, the results should be consistent when different teachers administer the test and or different teachers score them. The test results should also be consistent if they are given on different days. For example, if a test is given on two different dates and the results are very similar, then we can say that it is reliable. Of course, the result won't be identical because learners are human and won't always perform the same way on a different day or at a different time (Hughes, 1989).

\subsection{Formal Assessment}

Elementary school students in most countries are required to participate in mandated formal assessments that assess their native language reading and math skills. In addition, young learners are increasingly being required to participate in formalized Englishlanguage testing. These tests very greatly from country to country and 
often region to region within a specific country. This type of assessment may be administered on a one-to-one basis or given to a group of young learners in the form of a written test. In the case of public schools, the tests are mandated by the Ministry of Education or the state or local school district. In the case of private schools and institutes, the administration may require students to be assessed using standardized test instruments. As a teacher, if one of your students has moved from another country, you should try and obtain any assessment information that the child may have received prior to moving.

As a teacher, if your students are required to take standardized tests, you should ask the administration whether the test instruments and the items on the test are valid and reliable for your learners. You want to make sure that the test developer piloted the test with students who are similar to yours. It is not uncommon for private school administrators in English as a Foreign Language (EFL) settings to want to use English as a Second Language (ESL) tests to show progress. Private school administrators may feel pressured by parents to show that the progress students have made in their English language development is comparable to the progress that ESL learners have made. Unfortunately, the tests designed for ESL have not always proven to be valid with children in EFL settings.

In recent years, tests have been introduced for children in the countries where English is a foreign language. Probably the most wellknown tests are the Cambridge Young Learners Tests developed by the University of Cambridge ESOL Examinations. These tests have been piloted in many different countries with different learners to assure a high level of validity and reliability. If your EFL school insists on using a standardized test, you may want to recommend the Cambridge tests. 


\subsection{Classroom-based Assessment}

I like to weave assessment and instruction together and try to constantly observe my learners so that I can adjust my instruction to meet their needs. Assessment should be integrated and reflect the type of instruction taking pale in the classroom. Many oral and written language activities can easily be used for classroom based assessment. Most teaching activities can be used for assessment when there is criteria, including an aim, as well as a feedback mechanism. Before using an activity as an assessment tool, it is important to determine what type of assessment information you will gain from the activity. For instance, children may do an activity sheet where they answer questions about a story. Based on the children's answer, you can determine how well they have comprehended the story. We will now look at instructional activities which will help you to assess your students' progress in the four main language skills (listening, speaking, reading, writing). We will also look at using portfolios as assessment tools.

\section{Listening skills}

There are two main components of listening assessment in the young-learner classroom. The first is the assessment of phonemic awareness-the ability to distinguish between different sounds. The importance of listening assessment is phonemic awareness. The second components of listening assessment is listening comprehension. Listening skill rubric as follows:

EXCELLENT - 5 - The student is attentive, courteous and sensitive to the ideas, tone and purpose of the presentation; intellectual curiosity, attention to the task, and sensitivity to 
others help to create a productive climate in and for the group.

PROFICIENT - 4 - The student is attentive and courteous; purposefully and confidently listens to the presentation.

SATISFACTORY - 3 - The student is courteous and willing to listen to others; accepts ideas of others.

LIMITED - 2 - The student is easily distracted; lacks confidence to receive ideas easily and clearly; may use language, tone, or nonverbal behavior inappropriate for the occasion; is an insecure member of the group.

POOR - 1 - The student is uninvolved in the activity and lacks courtesy.

\section{Speaking skills}

Speaking skill can be assessed by asking young learners questions and engaging them conversations. You can assess students by asking specific questions during class, as well as by talking with them on a one-to-one basis. When assessing learners' oral skills, you may want to use an analytical or holistic rubric. A holistic rubric provides one overall score. An analytic rubric provides information broken down into different categories.

\section{Level 1 Speaking Tasks Analytic Rubric} Task Completion: 
1 Minimal completion of the task and/or responses frequently inappropriate.

2 Partial completion of the task; responses mostly appropriate yet undeveloped.

3 Completion of the task; responses appropriate and adequately developed.

4 Superior completion of the task; responses appropriate and with elaboration.

\section{Comprehensibility:}

1 Responses barely comprehensible.

2 Responses mostly comprehensible, requiring interpretation on the part of the listener.

3 Responses comprehensible, requiring minimal interpretation on the part of the listener.

4 Responses readily comprehensible, requiring no interpretation on the part of the listener.

\section{Fluency:}

1 Speech halting and uneven with long pauses and/or incomplete thoughts.

2 Speech choppy and/or slow with frequent pauses; few or no incomplete thoughts.

3 Some hesitation but manages to continue and complete thoughts.

4 Speech continuous with few pauses or stumbling.

\section{Pronunciation:}

1 Frequently interferes with communication.

2 Occasionally interferes with communication.

3 Does not interfere with communication.

4 Enhances communication. 


\section{Vocabulary:}

1 Inadequate and/or inaccurate use of vocabulary.

2 Somewhat inadequate and/or inaccurate use of vocabulary.

3 Adequate and accurate use of vocabulary.

4 Rich use of vocabulary.

\section{Language Control:}

1 Inadequate and/or inaccurate use of basic language structures. 2 Emerging use of basic language structures.

3 Emerging control of basic language structures.

4 Control of basic language structures.

https://washburn.mpls.k12.mn.us/uploads/level 1 analytic speaking.pdf

\section{Assessing Reading Skills}

Assessing students' literacy skill is a complex process (Hurley and Tinajero, 2001). It is especially difficult when students are learning ESL or EFL.in addition to assessing if students can decode, sound out, or pronounce the words, you will also want to assess their ability to comprehend written text. Comprehension questions can be used to determine if children understand a specific reading passage.

Other techniques can also be used. One very effective technique is a story map-graphic summary of a story. A story map can help you determine if students understand the main ideas of stories. Two the most common story maps are the story elements map and the sequence of events story map. For a story map, children are asked to describe the different parts-or elements of a story. Specifically, young learners are 
asked to describe the setting and characters. Learners can also be asked to describe the conflict and resolution. When using a story elements map, tailor the descriptions of each section of the map to your students' language and literacy levels. In the reproducible story elements map, you will notice there are descriptions (setting, characters, conflict, and resolution) as well as questions.

When using the map with students, you would choose which of these you would use. You would also decide if the children would write their answer in each section or draw pictures. A sequence of events story map chronicles what took place first, second, etc. it helps young learners focus on the most important events in the story. Like the story elements map, children can write their responses or draw pictures to indicate what happened.

\section{Rubric for Oral Reading Fluency}

adapted from the National Assessment of Educational Progress (NAEP) Scale for Assessing Oral Reading Fluency

\begin{tabular}{|c|l|}
\hline $\begin{array}{c}\text { Point } \\
\text { Scale }\end{array}$ & Description of Oral Reading Fluency \\
\hline 4 & $\begin{array}{l}\text { Reads primarily in large, meaningful phrase } \\
\text { groups. Although some regressions, } \\
\text { repetitions, and deviations from text may be } \\
\text { present, these do not appear to detract from } \\
\text { the overall structure of the story. Preservation } \\
\text { of the author's syntax is consistent. Some or } \\
\text { most of the story is read with expressive } \\
\text { interpretation. }\end{array}$ \\
\hline 3 & $\begin{array}{l}\text { Reads primarily in three- or four-word phrase } \\
\text { groups. Some smaller groupings may be } \\
\text { present. However, the majority of phrasing }\end{array}$ \\
\hline
\end{tabular}




\begin{tabular}{|c|l|}
\hline & $\begin{array}{l}\text { seems appropriate and preserves the syntax } \\
\text { of the author. Little or no expressive } \\
\text { interpretation is present. }\end{array}$ \\
\hline 2 & $\begin{array}{l}\text { Reads primarily in two-word phrases with } \\
\text { some three- or four-word groupings. Some } \\
\text { word-by-word reading may be present. Word } \\
\text { groupings may seem awkward and unrelated } \\
\text { to the larger context of the sentence or } \\
\text { passage. }\end{array}$ \\
\hline 1 & $\begin{array}{l}\text { Reads primarily word by word. Occasional two- } \\
\text { word or three-word phrases may occur, but these } \\
\text { are infrequent and/or they do not preserve } \\
\text { meaningful syntax. }\end{array}$ \\
\end{tabular}

https://dese.mo.gov/sites/default/files/ela-6-

my portfolio anecdotal-summative assessment 2oral reading fluency rubric.pdf

\section{Writing assessment}

Writing is assessed by eliciting and examining a sample of writing. The learners can write a sample consisting of a sentence, paragraph, or essay. This sample can be fiction or nonfiction and can be assessed using an analytic or holistic rubric. Just as with speaking assessment, an analytical score is a broker, down into categories, and a holistic score is an overall score. However, the categories that are used with an analytical speaking rubric.

Basic Writing Rubric 


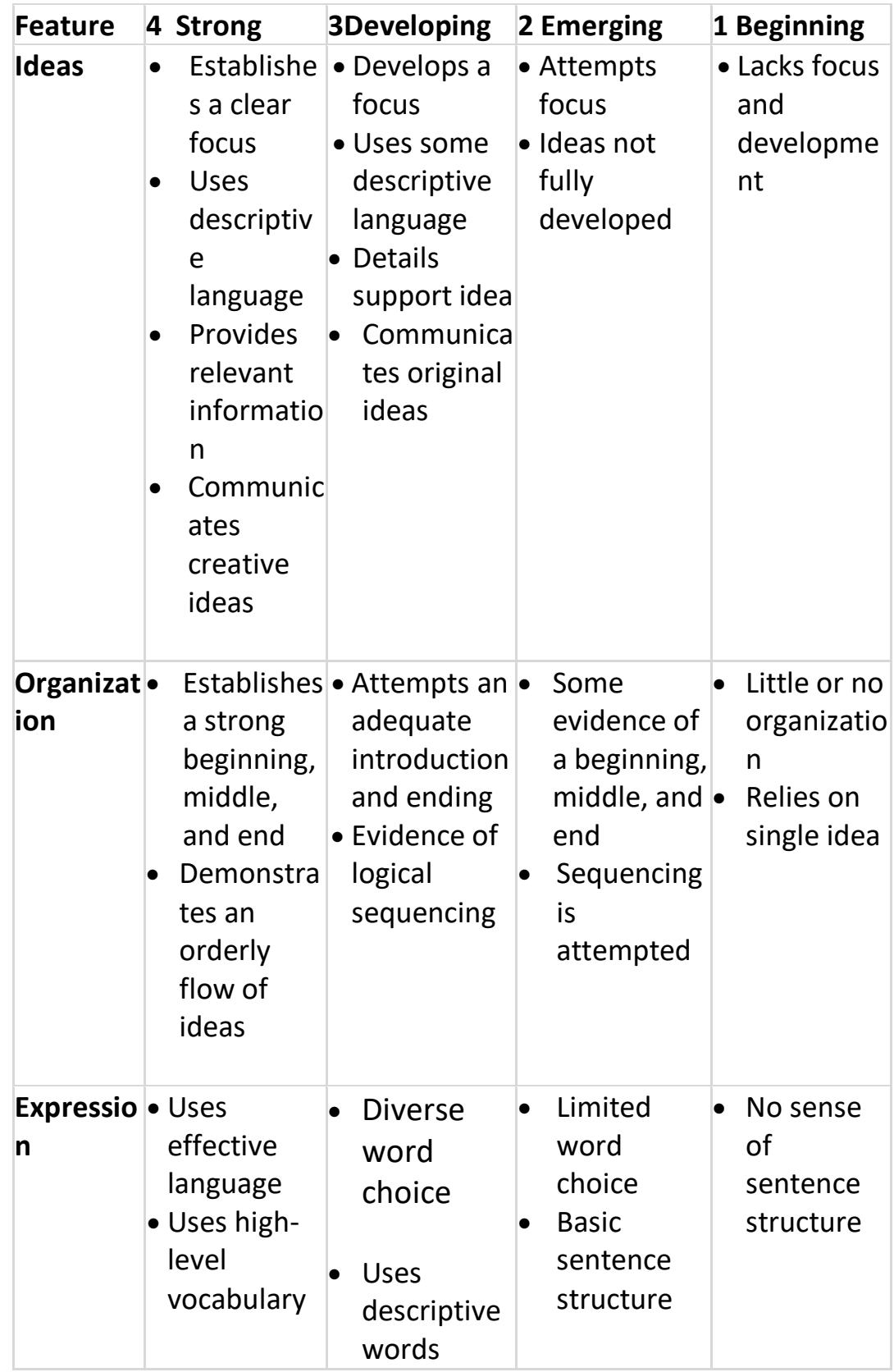




\begin{tabular}{|c|c|c|c|c|}
\hline & $\begin{array}{l}\text { - Use of } \\
\text { sentence } \\
\text { variety }\end{array}$ & $\begin{array}{l}\text { - Sentence } \\
\text { variety }\end{array}$ & & \\
\hline $\begin{array}{l}\text { Conventi } \\
\text { ons }\end{array}$ & $\begin{array}{l}\text { - Few or no } \\
\text { errors in: } \\
\text { grammar, } \\
\text { spelling, } \\
\text { capitalizati } \\
\text { on, } \\
\text { punctuatio } \\
\text { n }\end{array}$ & $\begin{array}{l}\text { - Some } \\
\text { errors } \\
\text { in: } \\
\text { grammar, } \\
\text { spelling, } \\
\text { capitalization, } \\
\text { punctuation }\end{array}$ & $\begin{array}{l}\text { - Has some } \\
\text { difficulty in: } \\
\text { grammar, } \\
\text { spelling, } \\
\text { capitalization, } \\
\text { punctuation }\end{array}$ & $\begin{array}{l}\text { - Little or no } \\
\text { evidence } \\
\text { of correct } \\
\text { grammar, } \\
\text { spelling, } \\
\text { capitalizati } \\
\text { on or } \\
\text { punctuatio } \\
\mathrm{n}\end{array}$ \\
\hline Legibility & $\begin{array}{l}\text { - Easy to read } \\
\text { - Properly } \\
\text { spaced } \\
\text { - Proper } \\
\text { letter } \\
\text { formation }\end{array}$ & $\begin{array}{l}\text { Readable } \\
\text { with some } \\
\text { spacing/for } \\
\text { ming errors }\end{array}$ & $\begin{array}{l}\text { Difficult to } \\
\text { read due to } \\
\text { spacing/for } \\
\text { ming letter }\end{array}$ & $\begin{array}{l}\text { - No } \\
\text { evidence of } \\
\text { spacing/for } \\
\text { ming letters }\end{array}$ \\
\hline
\end{tabular}

Narrative Writing Rubric

\begin{tabular}{|c|c|c|c|c|}
\hline Criteria & $\begin{array}{l}4 \\
\text { Advanced }\end{array}$ & $\begin{array}{l}3 \\
\text { Proficient }\end{array}$ & $\begin{array}{l}2 \\
\text { Basic }\end{array}$ & $\begin{array}{l}1 \\
\text { Not There Yet }\end{array}$ \\
\hline $\begin{array}{l}\text { Main } \\
\text { Idea \& } \\
\text { Focus }\end{array}$ & $\begin{array}{l}\text { - Skillfully } \\
\text { combines } \\
\text { story } \\
\text { elements }\end{array}$ & $\begin{array}{l}\text { - Combines } \\
\text { story } \\
\text { elements } \\
\text { around } \\
\text { main idea }\end{array}$ & $\begin{array}{l}\text { - Story } \\
\text { elements } \\
\text { do not } \\
\text { reveal a } \\
\text { main idea }\end{array}$ & $\begin{array}{l}\text { There is no } \\
\text { clear main } \\
\text { idea }\end{array}$ \\
\hline
\end{tabular}




\begin{tabular}{|c|c|c|c|c|}
\hline & $\begin{array}{l}\text { around } \\
\text { main idea } \\
\text { - Focus on } \\
\text { topic is } \\
\text { profoundl } \\
\text { y clear }\end{array}$ & $\begin{array}{l}\text { - Focus on } \\
\text { topic is } \\
\text { clear }\end{array}$ & $\begin{array}{l}\text { - Focus on } \\
\text { topic is } \\
\text { somewhat } \\
\text { clear }\end{array}$ & $\begin{array}{l}\text { - Focus on } \\
\text { topic is not } \\
\text { clear }\end{array}$ \\
\hline $\begin{array}{l}\text { Plot \& } \\
\text { Narrative } \\
\text { Devices }\end{array}$ & $\begin{array}{l}\text { - Characters, } \\
\text { plot, and } \\
\text { setting are } \\
\text { developed } \\
\text { strongly } \\
\text { - Sensory } \\
\text { details and } \\
\text { narratives } \\
\text { are } \\
\text { skillfully } \\
\text { evident }\end{array}$ & $\begin{array}{l}\text { - Characters } \\
\text {, plot, and } \\
\text { setting are } \\
\text { developed } \\
\text { - Sensory } \\
\text { details and. } \\
\text { narratives } \\
\text { are } \\
\text { evident }\end{array}$ & $\begin{array}{l}\text { - Characters } \\
\text {, plot, and } \\
\text { setting are } \\
\text { minimally } \\
\text { developed } \\
\text { - Attempts } \\
\text { to use } \\
\text { narratives } \\
\text { and } \\
\text { sensory } \\
\text { details }\end{array}$ & $\begin{array}{l}\text { - Lacks } \\
\text { development } \\
\text { on } \\
\text { characters, } \\
\text { plot, and } \\
\text { setting } \\
\text { - Fails to use } \\
\text { sensory } \\
\text { details and } \\
\text { narratives }\end{array}$ \\
\hline $\begin{array}{l}\text { Organizati } \\
\text { on }\end{array}$ & $\begin{array}{l}\text { - Strong } \\
\text { and } \\
\text { engaging } \\
\text { descripti } \\
\text { on } \\
\text { - Sequencin } \\
\text { g of details } \\
\text { are } \\
\text { effective } \\
\text { and logical }\end{array}$ & $\begin{array}{l}\text { - Engaging } \\
\text { descriptio } \\
\mathrm{n} \\
\text { - Adequate } \\
\text { sequencing } \\
\text { of details }\end{array}$ & $\begin{array}{l}\text { - Descriptio } \\
\mathrm{n} \text { needs } \\
\text { some work } \\
\text { - Sequencin } \\
\mathrm{g} \text { is limited }\end{array}$ & $\begin{array}{l}\text { - Description a } \\
\text { nd } \\
\text { sequencing } \\
\text { needs major } \\
\text { revision }\end{array}$ \\
\hline Voice & $\begin{array}{l}\text { - Voice is } \\
\text { expressive }\end{array}$ & $\begin{array}{l}\text {-Voice is } \\
\text { authentic }\end{array}$ & $\begin{array}{l}\text { - Voice is } \\
\text { undefined }\end{array}$ & $\begin{array}{l}\text { - Writer's voice } \\
\text { is not evident }\end{array}$ \\
\hline
\end{tabular}




\begin{tabular}{|c|c|c|c|c|}
\hline & $\begin{array}{l}\text { and } \\
\text { confident }\end{array}$ & & & \\
\hline $\begin{array}{l}\text { Sentence } \\
\text { Fluency }\end{array}$ & $\begin{array}{l}\text { - Sentence } \\
\text { structure } \\
\text { enhances } \\
\text { meaning }\end{array}$ & $\begin{array}{l}\text { - Purposefu } \\
\text { I use of } \\
\text { sentence } \\
\text { structure }\end{array}$ & $\begin{array}{l}\text { Sentence } \\
\text { structure } \\
\text { is limited }\end{array}$ & $\begin{array}{l}\text { No sense of } \\
\text { sentence } \\
\text { structure }\end{array}$ \\
\hline $\begin{array}{l}\text { Conventio } \\
\text { ns }\end{array}$ & $\begin{array}{l}\text { A strong } \\
\text { sense of } \\
\text { writing } \\
\text { conventio } \\
\text { ns is } \\
\text { apparent }\end{array}$ & $\begin{array}{l}\text { - Standard } \\
\text { writing } \\
\text { conventio } \\
\text { ns is } \\
\text { apparent }\end{array}$ & $\begin{array}{l}\text { - Grade } \\
\text { level } \\
\text { appropria } \\
\text { te } \\
\text { conventio } \\
\text { ns }\end{array}$ & $\begin{array}{l}\text { - Limited use } \\
\text { of } \\
\text { appropriate } \\
\text { conventions }\end{array}$ \\
\hline
\end{tabular}

Expository Writing Rubric

\begin{tabular}{|c|c|c|c|c|}
\hline \multirow{2}{*}{ Criteria } & 4 & 3 & 2 & 1 \\
\hline & $\begin{array}{l}\text { Displays } \\
\text { EvidenceBeyo } \\
\text { nd }\end{array}$ & $\begin{array}{l}\text { Consistent } \\
\text { Evidence }\end{array}$ & $\begin{array}{l}\text { Some } \\
\text { Evidence }\end{array}$ & $\begin{array}{l}\text { Little/No } \\
\text { Evidence }\end{array}$ \\
\hline Ideas & $\begin{array}{l}\text { Informative } \\
\text { with clear } \\
\text { focus and } \\
\text { supporting } \\
\text { details }\end{array}$ & $\begin{array}{l}\text { Informati } \\
\text { ve with } \\
\text { clear } \\
\text { focus }\end{array}$ & $\begin{array}{l}\text { Focus } \\
\text { needs to } \\
\text { be } \\
\text { expanded } \\
\text { and } \\
\text { supporting } \\
\text { details are } \\
\text { needed }\end{array}$ & $\begin{array}{l}\text { - Topic } \\
\text { needs to } \\
\text { be } \\
\text { developed }\end{array}$ \\
\hline
\end{tabular}




\begin{tabular}{|c|c|c|c|c|}
\hline $\begin{array}{l}\text { Organizati } \\
\text { on }\end{array}$ & $\begin{array}{l}\text { Very well } \\
\text { organized; } \\
\text { easy to read }\end{array}$ & $\begin{array}{l}\text { - Has a } \\
\text { beginning } \\
\text {, middle } \\
\text { and end }\end{array}$ & $\begin{array}{l}\text { Little } \\
\text { organizatio } \\
\text { n; needs } \\
\text { transitions }\end{array}$ & $\begin{array}{l}\text { Organizati } \\
\text { on is } \\
\text { needed }\end{array}$ \\
\hline Voice & $\begin{array}{l}\text { - Voice is } \\
\text { confident } \\
\text { throughout }\end{array}$ & $\begin{array}{l}\text { - Voice is } \\
\text { confiden } \\
t\end{array}$ & $\begin{array}{l}\text { - Voice is } \\
\text { somewhat } \\
\text { confident }\end{array}$ & $\begin{array}{l}\text { Little to no } \\
\text { voice; } \\
\text { needs } \\
\text { confidence }\end{array}$ \\
\hline $\begin{array}{l}\text { Word } \\
\text { Choice }\end{array}$ & $\begin{array}{l}\text { - Nouns and } \\
\text { verbs make } \\
\text { essay } \\
\text { informative }\end{array}$ & $\begin{array}{l}\text { - Use of } \\
\text { nouns } \\
\text { and } \\
\text { verbs }\end{array}$ & $\begin{array}{l}\text { - Needs } \\
\text { specific } \\
\text { nouns and } \\
\text { verbs; too } \\
\text { general }\end{array}$ & $\begin{array}{l}\text { - Little to no } \\
\text { use of } \\
\text { specific } \\
\text { nouns and } \\
\text { verbs }\end{array}$ \\
\hline $\begin{array}{l}\text { Sentence } \\
\text { Fluency }\end{array}$ & $\begin{array}{l}\text { - Sentences } \\
\text { flow } \\
\text { throughout } \\
\text { piece }\end{array}$ & $\begin{array}{l}\text { - Sentence } \\
\text { s mostly } \\
\text { flow }\end{array}$ & $\begin{array}{l}\text { - Sentences } \\
\text { need to } \\
\text { flow }\end{array}$ & $\begin{array}{l}\text { - Sentences } \\
\text { are } \\
\text { difficult to } \\
\text { read and } \\
\text { do not } \\
\text { flow }\end{array}$ \\
\hline $\begin{array}{l}\text { Convention } \\
\text { S }\end{array}$ & ค - Zero errors & $\begin{array}{l}\text { - Few } \\
\text { errors }\end{array}$ & $\begin{array}{l}\text { - Several } \\
\text { errors }\end{array}$ & $\begin{array}{l}\text { - Many } \\
\text { errors } \\
\text { make it } \\
\text { hard to } \\
\text { read }\end{array}$ \\
\hline
\end{tabular}

https://www.thoughtco.com/writing-rubric-2081370 
